\title{
Lipolysis and Proteolysis in Ragusano Cheese During Brine Salting at Different Temperatures*
}

\author{
C. Melilli, ${ }^{1}$ D. M. Barbano, ${ }^{2}$ M. Manenti, ${ }^{1}$ J. M. Lynch, ${ }^{2}$ S. Carpino, ${ }^{1}$ and G. Licitra ${ }^{1,3}$ \\ ${ }^{1}$ CoRFiLaC, Regione Siciliana, 97100 Ragusa, Italy \\ ${ }^{2}$ Northeast Dairy Food Research Center, Department of Food Science, \\ Cornell University, Ithaca, NY 14853 \\ ${ }^{3}$ Dipartimento di Scienze Agronomiche, Agrochimiche e delle Produzioni Animali, \\ Catania University, Via Valdisavoia 5, 95100 Catania, Italy
}

\begin{abstract}
The influence of temperature $(12,15,18,21$, and $24^{\circ} \mathrm{C}$ ) of saturated brine on lipolysis and proteolysis in 3.8-kg blocks of Ragusano cheese during $24 \mathrm{~d}$ of brining was determined. Twenty-six 3.8-kg blocks were made on each day. The cheese making was replicated on 3 different days. All blocks were labeled and weighed prior to brining. One block was sampled and analyzed prior to brine salting. Five blocks were placed into each of 5 different brine tanks at different temperatures. One block was removed from each brine tank after 1 , $4,8,16$, and $24 \mathrm{~d}$ of brining, weighed, sampled, and analyzed. Both proteolysis and lipolysis in Ragusano cheese increased with increasing brine temperature (from 12 to $24^{\circ} \mathrm{C}$ ), with the impact of brine temperature on proteolysis and lipolysis becoming progressively larger. Proteolysis was highest in the interior of the blocks where salt in moisture content was lowest and temperature had more impact on proteolysis in the interior position of the block than the exterior position. However, the opposite was true for lipolysis. The total free fatty acid content was higher and temperature had more impact on lipolysis at the exterior position of the block where salt in moisture was the highest. This effect of increased salt concentration on lipolysis was confirmed with direct salted cheeses in a small follow-up experiment. Lipolysis increased with increasing salt in the moisture content of the direct salted cheeses. It is likely that migration of water-soluble FFA from the brine into the cheese and from the interior portion of the cheese to the exterior portion of the cheese also contributed to a higher level of FFA at the exterior
\end{abstract}

Received October 5, 2003.

Accepted January 6, 2004.

Corresponding author: D. M. Barbano; e-mail: dmb37@cornell.edu.

*Use of names, names of ingredients, and identification of specific models of equipment is for scientific clarity and does not constitute any endorsement of product by authors, Cornell University, the Northeast Dairy Foods Research Center, CoRFiLaC, and Dipartimento di Scienze Agronomiche, Agrochimiche e delle Produzioni Animali, Catania University. portion of the blocks. As brine temperature increased the profile of individual free fatty acids released from triglycerides changed, with the proportion of shortchain free fatty acids increasing with increasing brine temperature. This effect was largest at high salt in moisture content.

(Key words: free fatty acids, lipolysis, proteolysis, Ragusano cheese)

Abbreviation key: $\mathbf{C H M}=$ chloroform-heptane-methanol, $\mathbf{S N}=$ soluble nitrogen.

\section{INTRODUCTION}

Ragusano cheese is a brine-salted, pasta filata cheese (aged 3 to $12 \mathrm{mo}$ ) that is still produced on farms in the eastern region of Sicily (Licitra et al., 1998, 2000). Ragusano cheese is produced with rennet paste as the milk coagulant. A large amount of proteolysis and lipolysis takes place during aging, with approximately 9 to $12 \%$ of the TN present as $\mathrm{pH} 4.6$ acetate buffer soluble nitrogen (SN) and about 6.4 to $8.3 \%$ of TN present as $12 \%$ TCA SN after $180 \mathrm{~d}$ of aging and total FFA content of about $640 \mathrm{mg} / 100 \mathrm{~g}$ of cheese (Licitra et al., 2000). This combination of proteolysis and lipolysis make a major contribution to the typical aroma, flavor, and texture of Ragusano cheese. Ragusano cheese is brine salted and therefore large salt and moisture gradients are present within each block of cheese with characteristically high salt and low moisture near the surface and the opposite in the center of the block (Melilli et al., 2003a). These gradients in salt and moisture have been shown to influence proteolysis in Ragusano cheese (Licitra et al., 2000), but there is little data available on the influence of salt and moisture gradients on lipolysis in hard cheeses. It might be expected that high concentrations of salt in the exterior portions of a block of cheese may inhibit lipase activity, as it does protease activity. In general, both proteolysis and lipolysis would be expected to be faster at higher temperature. Previous studies (Geurts et al., 1974; Turhan and Kaletunç, 1992) on the impact of brine temperature have found 
that increasing brine temperature increases the rate of salt penetration in cheese. While there are data on proteolysis and lipolysis in many cheeses during aging after brining, there is relatively little data available on the extent of proteolysis and lipolysis in cheese during the brining process before the initiation of aging. During this time period, which can be $24 \mathrm{~d}$ or longer for some Italian hard cheeses, there are very large salt and moisture gradients that develop within the blocks (Resmini et al., 1974; Guinee and Fox, 1983, 1986; Melilli et al., 2003a,b). The objective of the present study was to determine the impact of 5 different temperatures $\left(12,15,18,21\right.$, and $\left.24^{\circ} \mathrm{C}\right)$ of a saturated salt brine on lipolysis and proteolysis in Ragusano cheese.

\section{MATERIALS AND METHODS}

\section{Experimental Design and Statistical Analysis}

To determine the impact of brine temperature on proteolysis and lipolysis, 5 different temperatures of saturated brine were used: $12,15,18,21$, and $24^{\circ} \mathrm{C}$ for $24 \mathrm{~d}$. The 5 temperature treatments were done on cheese made from the same milk on each day of the 3 $\mathrm{d}$ of cheese manufacture. Data were analyzed using the GLM procedure of SAS (version 8, 1999, SAS Institute, Cary, NC) using a significance level of $P<0.05$. The ANOVA models used for analysis are provided in the data tables. Cheese samples were taken at $0,1,4,8$, 16 , and $24 \mathrm{~d}$ of brining. Time of brining was treated as a continuous variable in the split-plot ANOVA models; therefore, the linear and quadratic terms of time would be correlated. Distortion of the ANOVA by multicollinearity of these terms in the model was minimized by centering the time of brining data using a mathematical transformation (Glantz and Slinker, 2001). Time was transformed as follows: time $=\mathrm{d}$ of brining $-[$ (last testing day - first testing day)/2]. This transformation made the data set orthogonal with respect to time. This transformation directs the ANOVA model to consider the effect of brine temperature (T) in the whole plot at the midpoint of time of brining (i.e., d 12).

\section{Cheese Making}

Fifteen days before the experiment, a mature saturated brine was transported from a traditional aging center to CoRFiLaC's pilot plant, because it would contain a normal calcium content and have a normal $\mathrm{pH}$, compared with a freshly made brine. Calcium content of the brine was measured using a complexometric method (Kindstedt and Kosikowski, 1985). The mature salt brine had a calcium concentration $0.11 \%$ and a $\mathrm{pH}$ of 5.20. The old brine was filtered and divided in 5 brine tanks. Each tank was placed in a temperature controlled room set at one of the following temperatures: $12,15,18,21$, and $24^{\circ} \mathrm{C}$.

Milk produced by Brown Swiss and mixed breed cows from 2 farms, from the 2 milkings (morning and evening) was collected and transported to the CoRFiLaC pilot plant, where Ragusano cheese was manufactured using the procedures described by Melilli et al. (2003a, 2003b). After ripening, the curd was cut into long, uniform, 1-cm thick slices, weighed, and divided into 26 batches of 4-kg each. Three cheese makers stretched 26 batches of curd, producing 26 blocks of cheese (15.2 $\times 15.2 \times 15.2 \mathrm{~cm})$. The weight of each block of cheese decreased during stretching from about 4 to $3.8 \mathrm{~kg}$. Each cheese was promptly marked with a letter (treatment) and a number (sampling day) so that the cheese could be correctly identified in the brine tanks. After forming the blocks $\left(18 \mathrm{~h}\right.$ at $18^{\circ} \mathrm{C}$ ), one of the 26 blocks was analyzed prior to brining. The remaining 25 blocks were divided into 5 groups and each group was placed into saturated salt brine at a different temperature (12, $15,18,21$, and $\left.24^{\circ} \mathrm{C}\right)$. The blocks were kept submerged for $24 \mathrm{~d}$. Every day the salt brines were stirred and checked several times for temperature, salt concentration (using a Baumé hydrometer, 1 to $30^{\circ} \mathrm{B}$, Sacco s.r.l., Milan, Italy), and $\mathrm{pH}$. The cheese making was replicated 3 times.

\section{Sampling and Analysis of Cheese}

Cheeses were sampled at 0 time (before brining), 1 , $4,8,16$, and $24 \mathrm{~d}$. Each experimental block of Ragusano cheese, at the sampling day, was weighed and divided into 4 portions $\mathrm{P} 1, \mathrm{P} 2, \mathrm{P} 3$, and $\mathrm{P} 4$, as described by Melilli et al. (2003a), using a meat slicer (model 601003, Electrolux, Zanussi Italia s.p.a, Pordenone, Italy). Each of the 4 portions was approximately $25 \%$ of the weight of the block of the cheese. The exterior portion (P1) represented all 6 faces of the block (approximately 0.6 $\mathrm{cm}$ thick). The P2 portion was removed (approximately $1 \mathrm{~cm}$ thick), after removal of the P1 portion, from all the 6 faces of the block, followed by removal of the P3 portion (approximately $1 \mathrm{~cm}$ thick). The cube remaining of about $10 \times 10 \times 10 \mathrm{~cm}$ was the central portion (P4).

Each portion (P1, P2, P3, and P4) was weighed, cut into cubes, and ground. Moisture, fat, salt content, and $\mathrm{pH}$ were determined and have been reported previously (Melilli et al., 2003b). Total FFA content of each portion of each cheese at each brine temperature $(12,15,18$, 21 , and $24^{\circ} \mathrm{C}$ ) was measured at $0,1,4,8,16$, and $24 \mathrm{~d}$ of brining using a modified copper soap method. The concentration of individual FFA in the P2 and P4 portion of each cheese at the brine temperatures of 12,18 , and $24^{\circ} \mathrm{C}$ were measured at $0,4,8$, and $24 \mathrm{~d}$ of brining using a method that recovered the FFA from an ether 
extract of the cheese using a resin-binding technique followed by GLC analysis. Kjeldahl nitrogen analysis was used to determine total nitrogen using a 1-g sample size (AOAC, 2000; method number 33.2.11, 991.20) for cheese. The pH 4.6 acetate buffer SN and $12 \%$ TCA SN were determined (Bynum and Barbano, 1985). The TN and SN analyses were only done on cheeses at $24 \mathrm{~d}$ of brining. The SN was expressed as a percentage of the total nitrogen. All analyses were done in duplicate.

Total FFA: copper soap method. The total FFA content was determined using the copper soap method (Shipe et al., 1980; Ma et al., 2003) as modified for cheese analysis.

The results were expressed in $\mathrm{mg}$ of FFA/100 g of cheese. Reagents used in the analysis were prepared as described by Shipe et al. (1980) unless specified. Cheeses were analyzed in sets of 20 samples. Ground cheese $(0.5 \mathrm{~g})$ at $4^{\circ} \mathrm{C}$ was weighed (to nearest $0.1 \mathrm{mg}$ ) into a tared screw-top centrifuge tube (Nalgene Oak Ridge Teflon FEP tube, $50 \mathrm{~mL}$, Fisher Scientific, NJ). Immediately after weighing, $0.2 \mathrm{~mL}$ of $0.7 \mathrm{~N} \mathrm{HCl}$ was added. The tube was capped, weighed, and vortexed to allow thorough mixing of the acid and cheese. Next, 0.2 $\mathrm{mL}$ of $1 \%$ (vol/vol) Triton-X 100 solution was added and the mixture was vortexed. The copper soap reagent (4 $\mathrm{mL}$ ) was added, and the mixture was vortexed again. Next, $12 \mathrm{~mL}$ of chloroform-heptane-methanol (CHM, 49:49:2, vol:vol:vol, HPLC grade) solvent was added to each tube without vortexing. The mixture had 2 distinct layers: the deep blue aqueous layer on the bottom and the colorless CHM solvent layer on the top.

Next, the centrifuge tubes containing the reagents plus cheese samples were shaken for $60 \mathrm{~min}$ in a basket attached to a Babcock shaker (Garver Shaker, Union City, IN) at a speed of $470 \mathrm{rpm}$ (dial setting 60 ). During shaking, the deep blue aqueous copper soap layer broke into pea-sized "beads" that were in continuous contact with the colorless solvent. When shaking was stopped, 2 distinct layers were quickly formed. After shaking, the tubes were centrifuged at $5000 \mathrm{rpm}(2500 \times \mathrm{g})$ for $10 \mathrm{~min}$ in a Sorvall Superspeed centrifuge (RC2-B, SA600 rotor, Wilmington, DE). The top colorless solvent layer $(3.5 \mathrm{~mL})$ was transferred from the centrifuge tube using a glass Pasteur pipette and transferred into an acid washed test tube $(10 \times 75 \mathrm{~mm})$ containing $0.1 \mathrm{~mL}$ of the color reagent. To keep the absorbance readings for samples within the range of absorbance of the standard curve, the volume of the colorless solvent layer was reduced for samples with high FFA content and then the total volume for that sample was made up to 3.5 $\mathrm{mL}$ with CHM solvent. The exact volume of the upper layer used for each sample needs to be included in the calculation of results. After mixing, absorbance was measured immediately at $440 \mathrm{~nm}$ in a cuvette with 1- cm path-length using a Spec 20 spectrophotometer $(20$ Genesys, Spectronic Instruments, Rochester, NY). Two blanks $(1.0 \mathrm{~mL}$ of deionized water instead of $0.5 \mathrm{~g}$ of cheese) were also prepared and analyzed with the cheese samples.

With each batch of 20 cheese samples, a standard curve was constructed using palmitic acid (GC grade crystal, MW $=256.43$, Alltech Associates, Inc., Deerfield, IL). Six concentrations of palmitic acid were prepared: $0,30,120,180,240$, and $300 \mu \mathrm{g}$ of palmitic acid/ $\mathrm{g}$ of hexane. The standards were stored at $-20^{\circ} \mathrm{C}$ in $2-$ $\mathrm{mL}$ GC glass vials $(12 \times 32 \mathrm{~mm})$ that were tightly sealed with PTFE lined screw caps (National Scientific, Lawrenceville, GA). On the first day of the analysis cycle, $1 \mathrm{~mL}$ of each standard was added to a screw-top centrifuge tube, and its weight was recorded. The hexane solvent was evaporated with nitrogen (high purity) under the hood. After the solvent was completely removed, $0.2 \mathrm{~mL}$ of $0.7 \mathrm{~N} \mathrm{HCl}$ and $1.0 \mathrm{~mL}$ of deionized water were added to the tube. A set of standards was carried through the full analysis with each group of 20 cheese samples and 2 blanks.

Absorbance readings of standards were corrected by subtracting the average of the 2 blank readings and a regression line was constructed, correlating the corrected absorbance with micrograms of palmitic acid. The absorbance reading of the blank was $<0.01$. The level of FFA in cheese, in micrograms of FFA, was calculated from the standard curve. The final result was expressed in units of $\mathrm{mg}$ of FFA/100 $\mathrm{g}$ of cheese.

Individual FFA measurement: resin binding/ GLC method. The method used to measure FFA in cheese is a modification of a general reference method described for dairy products (IDF, 1991). A cheese sample $(4 \mathrm{~g}$ of Ragusano at $<45 \mathrm{~d}$ and $1 \mathrm{~g}$ of Ragusano at $1 \mathrm{yr}$ of age) was weighed (to nearest $0.1 \mathrm{mg}$ ) and transferred to a modified Mojonnier flask. The modification of the Mojonnier flask was to convert the neck of the flask to a ground glass standard taper (19/26) stoppered flask. Sodium sulfate (anhydrous 12 to 60 mesh) was prepared by rinsing several times with hexane, decanting the hexane to remove fines, and then it was placed in a hood to allow the hexane vapors to evaporate, and dried in a forced-air oven $\left(100^{\circ} \mathrm{C}\right)$ overnight. Six grams of sodium sulfate was added to each Mojonnier flask (one per sample), including those for the blanks. A hydrochloric acid solution $(120 \mathrm{~mL}$ of a $35 \%$ aqueous $\mathrm{HCl}$ with $750 \mathrm{~mL}$ of water) was added $(17.4 \mathrm{~mL})$ to each flask. The flasks were swirled to thoroughly mix until the cheese dispersed completely. Two milliliters of the internal FFA standard C13:0 (1.4 mmole/L in diethyl ether, $\mathrm{MW}=214.34$ ) was added to each flask using a 2-mL Bang microburette (model number 0863 24595, Carlo ERBA, Milan, Italy). 
Twenty milliliters of diethyl ether was poured into the Mojonnier flask. The flasks were shaken by hand for $3 \mathrm{~min}$ and then centrifuged for $5 \mathrm{~min}$ at $600 \mathrm{rpm}$. The same conditions were used for 2 blanks. After centrifugation, the stopper was removed, and the ether phase was transferred without contamination from the water phase into a $100-\mathrm{mL}$ screw cap bottle containing approximately $6 \mathrm{~g}$ of dried sodium sulfate. The purpose of the sodium sulfate was to bind water. Twenty milliliters of diethyl ether was added to the Mojonnier flask for the second extraction. The flasks were shaken together for $3 \mathrm{~min}$ and then centrifuged for $5 \mathrm{~min}$ at 600 rpm. After centrifugation, the level of the aqueous/ether interface in the Mojonnier flask was raised, if necessary, by the addition of water, and then the $20 \mathrm{~mL}$ of ether extract was poured into the same $100-\mathrm{mL}$ glass bottle. The bottle contained about $40 \mathrm{~mL}$ of extract. The ether:sodium sulfate was mixed for $15 \mathrm{~s}$ and then let stand for $15 \mathrm{~min}$.

Silicic acid (100 to 200 mesh) was prepared by washing 3 times with a large volume of distilled water to remove fines. The wet silicic acid was dried in a $100^{\circ} \mathrm{C}$ forced air oven, activated by holding at $200^{\circ} \mathrm{C}$ for $48 \mathrm{~h}$, and stored in a desiccator. A slurry of $6 \mathrm{~g}$ of silicic acid and diethyl ether was poured into each glass column $(1.7 \mathrm{~cm}$ diameter $\times 35 \mathrm{~cm}$ height, with fritted glass disk at the bottom of the column to support the silicic acid and a Teflon stopcock to control the flow out of the column) for each sample. The silicic acid was allowed to settle on the glass frit, and then the ether was drained to a point just above the surface of the silicic and the flow was stopped. A $300-\mathrm{mL}$ bottle containing $65 \mathrm{~mL}$ of methanol and about $1 \mathrm{~g}$ of activated Amberlyst 26 resin was placed under the column for collection of the eluate.

Amberlyst (dry) A-26 resin (cat. no. 417761, Carlo ERBA, Milan, Italy) was activated before use. This was done by mixing $20 \mathrm{~g}$ of resin for 20 min with $200 \mathrm{~mL}$ of $1 \mathrm{~N} \mathrm{NaOH}$. The $\mathrm{NaOH}$ solution was decanted, and the resin was rinsed with $\mathrm{CO}_{2}$ free water until the $\mathrm{pH}$ of the water rinses were in the range of $\mathrm{pH} 5$ to 6 . During the water rinsing, nitrogen gas was bubbled through the water. The resin was rinsed 3 times with $150 \mathrm{~mL}$ of methanol, with $10 \mathrm{~min}$ of shaking for each rinse. The methanol was decanted, and the activated resin was stored in a tightly sealed container.

The $40 \mathrm{~mL}$ of ether extract of the cheese sample that contains sodium sulfate from the $100-\mathrm{mL}$ bottle was transferred to the silicic acid column. The sodium sulfate settled in a layer on the surface of the silicic acid. The stopcock at the bottom of the column was opened, and the eluate was collected in the $300-\mathrm{mL}$ bottle containing the resin plus methanol. Diethyl ether $(30 \mathrm{~mL})$ was added to the $100-\mathrm{mL}$ bottle as a rinse. Afterwards, the liquid level in the column was close to the upper surface of the column packing, the first $30 \mathrm{~mL}$ of diethyl ether rinse was added to rinse down the inside surfaces of the glass column above the bed. A second and third diethyl ether rinse (30 and $10 \mathrm{~mL}$, respectively) of the $100-\mathrm{mL}$ bottle and the column were done. The last 10 $\mathrm{mL}$ of rinse of the column was added when the level of ether from the second rinse reached the surface of column bed. All of the rinses were collected in the 300$\mathrm{mL}$ bottle. A screw cap was placed on each bottle, and they were swirled gently on a mixer (Vibrax IKA VXR, IKA-WERKE GmbH and Co., Staufen, Germany) for 2 $\mathrm{h}$ to allow the resin to bind the FFA. After $2 \mathrm{~h}$, the solvent was decanted. The residual solvent inside the 300-mL bottle contained a high concentration of neutral lipids that needed to be removed. Complete rinsing of the dissolved neutral lipid off the resin is very important. Thus, the resin plus the inside surfaces of the 300 -mL glass bottle were washed 5 times $(15 \mathrm{~mL}$ each time) with a 2:1 mixture of diethyl ether: methanol. The rinsed resin was transferred (using a Pasteur pipette) using $15 \mathrm{~mL}$ of the solvent mixture to a $25-\mathrm{mL}$ pearshaped standard taper flask that was used for methylation.

After the resin settled to the bottom of the pearshaped flask, excess solvent was removed with a Pasteur pipette. A gentle stream of dry nitrogen gas was used to evaporate the remaining solvent. One milliliter of a C17:0 methyl ester standard $(0.7 \mathrm{mmoles} / \mathrm{L}$; $\mathrm{MW}=284.49$ ) was added, using a 2-mL Bang microburette, and the ether was evaporated with nitrogen in a hood, being careful not to blow resin out of the flask. The purpose of the C17:0 standard was for quality control to evaluate the consistency of the automatic sample injector by monitoring the area count of $\mathrm{C} 17: 0$ peak from chromatogram to chromatogram. The C17:0 standard was not used in the calculation of the final results. Three or 4 hexane-rinsed boiling chips were added to each flask, followed by addition of $4 \mathrm{~mL}$ of $0.5 \mathrm{~N}$ methanolic potassium hydroxide. The flask was immediately connected to the bottom of a refluxing condenser, and the flask was placed into a $100^{\circ} \mathrm{C}$ sand bath and the mixture was boiled for $6 \mathrm{~min}$. After $6 \mathrm{~min}, 4 \mathrm{~mL}$ of 12 to $14 \%$ methanolic boron trifluoride was gradually added through the top of the condenser and boiled for $2 \mathrm{~min}$. After $2 \mathrm{~min}, 4 \mathrm{~mL}$ of hexane was gradually added to the flask through the top of the condenser and boiled for $1 \mathrm{~min}$. The flask was raised out of the sand bath and remained attached to the condenser until the mixture stopped boiling. The flask was disconnected from the condenser and enough saturated sodium chloride solution was added to half fill the flask. The flask was stoppered (14/23 standard taper ground glass) and mixed on a vortex mixer for $10 \mathrm{~s}$. The mixture was allowed to 
sit undisturbed for separation of the aqueous and solvent phases and then more saturated sodium chloride solution was added to float the hexane layer (top layer) into the neck of the flask. The hexane layer was transferred to a $16 \mathrm{~mm}$ O.D. $\times 125 \mathrm{~mm}$ screw top test tube. Saturated $\mathrm{NaCl}$ solution was added to the screw-top test tube, in a volume equal to the amount of hexane in the test tube (approximately $3 \mathrm{~mL}$ ). The test tube was capped with a PTFE-faced rubber-lined screw cap and mixed on a vortex mixer for $10 \mathrm{~s}$. The test tube was allowed to sit undisturbed for separation of the aqueous and solvent phases. A portion of the hexane (upper) layer was transferred to a GC vial containing layer of sodium sulfate on the bottom and capped. The injection volume was $1 \mu \mathrm{L}$.

In addition to the C13:0 internal standard, a simulated milk FFA quantitative reference standard was prepared as described by Lynch et al. (1992) to account for losses in the methylation procedure for different fatty acids and to compensate for differences in flameionization detector response for each individual fatty acid. In general, recovery of fatty acids is lower for the short-chain fatty acids. The mean (14 runs) recovery factors for C4, 6, 8, 10, 12, 14, 14:1, 16, 16:1, 18, 18:1, and $18: 2$ were $0.37,0.74,0.97,1.01,1.07,1.08,1.06$, $1.08,1.03,0.99,1.00$, and 0.99 , respectively. The standard deviation of the recovery factor for all of the individual fatty acids ranged from 0.02 to 0.03 . The low, but consistent, recovery of the $\mathrm{C} 4$ and $\mathrm{C} 6$ were primarily due to the partitioning of these methyl esters between the hexane and the saturated salt solution used in the methylation step.

The GLC (Varian Star model 3400 with Varian 8100 autosampling, Varian, Torino, Italy) was equipped with a capillary column (50\% cyanopropyl-phenyl-methyl-/ $50 \%$ dimethyl-siloxane) $30 \mathrm{~m} \times 0.53 \mathrm{~mm}$ with a film thickness of $1 \mu \mathrm{m}$ (DB-225, J \& W, Alltech Italia srl, Milan, Italy) using nitrogen as the carrier gas at a flow of $9.1 \mathrm{~mL} / \mathrm{min}$. The injection port temperature was $220^{\circ} \mathrm{C}$, the column temperature was programmed from 50 to $60^{\circ} \mathrm{C}$ at $10^{\circ} \mathrm{C} / \mathrm{min}$, held at $60^{\circ} \mathrm{C}$ for $2.5 \mathrm{~min}, 60$ to $160^{\circ} \mathrm{C}$ in $20^{\circ} \mathrm{C} / \mathrm{min}$, held at $160^{\circ} \mathrm{C}$ for $1 \mathrm{~min}, 160$ to $190^{\circ} \mathrm{C}$ at $2.5^{\circ} \mathrm{C} / \mathrm{min}$, held at $190^{\circ} \mathrm{C}$ for $9 \mathrm{~min}, 190$ to $210^{\circ} \mathrm{C}$ at $30^{\circ} \mathrm{C} / \mathrm{min}$, and held at $210^{\circ} \mathrm{C}$ for $3 \mathrm{~min}$. The detector temperature was $300^{\circ} \mathrm{C}$.

The concentration of individual free fatty acid was calculated as follows:

$$
F F A_{i}=\frac{F F A_{13}}{A_{13}} \cdot \frac{F F A_{i}^{*}}{\sum_{i=1}^{n} F F A_{i}^{*}} \cdot A_{i} \cdot \frac{z}{\sum_{j=1}^{Z} \frac{A_{j i}^{*}}{\sum_{i=1}^{n} A_{j i}^{*}}} \cdot \frac{100}{C W}
$$

Where:

$\mathrm{FFA}_{i}=\mathrm{mg}$ of the ith FFA per $100 \mathrm{~g}$ of cheese.

$\mathrm{FFA}_{13}=\mathrm{mg}$ of $\mathrm{C} 13 \mathrm{FFA}$ internal standard added to the sample.

$\mathrm{FFA}_{i}^{*}=\mathrm{mg}$ of the ith FFA in the simulated milk fat mixed fatty acid GLC recovery factor $\sum^{n} \quad$ standard.

$\sum_{i=1} F F A_{i}^{*}=$ sum of the mg of FFA from the ith to the nth free fatty acid in the standard.

$\mathrm{A}_{13}=$ peak area of the C $13 \mathrm{FFA}$ added to the sample.

$\mathrm{A}_{\mathrm{i}}=$ peak area of the ith FFA in the sample.

$\mathrm{A}_{j i}^{*}=$ peak area of the ith FFA for the jth injection of the mixed GLC recovery factor

$\sum^{n} \quad$ standard.

$\begin{aligned} \sum_{i=1} A_{j i}^{*}= & \text { sum of the peak areas for the jth injection } \\ & \text { of the ith to nth FFA in the simulated milk }\end{aligned}$ fat recovery factor standard.

$\mathrm{CW}=$ cheese weight in grams .

$\mathrm{z}=$ number of injections of the mixed GLC standard.

\section{RESULTS}

\section{Impact of Brine Temperature} on Proteolysis and Lipolysis

Proteolysis. Proteolysis was measured in cheeses after $24 \mathrm{~d}$ of brining. Proteolysis as indicated by $\mathrm{pH} 4.6$ SN acetate buffer SN and $12 \%$ TCA SN as a percentage of TN, increased $(P<0.01)$ with increasing brine temperature (Table 1 and Figure 1). There was also a significant effect of position $(P<0.01)$ within the block (Table 1) with higher proteolysis (Figures 2 and 3 ) occurring in the interior of the block (P4) vs. the exterior of the block (P1). The effect of position within block on both $\mathrm{pH} 4.6$ acetate buffer and $12 \%$ TCA SN as a percentage of TN was larger than the average effect of brine temperature (Table 2). There also was a significant impact of the interaction of temperature by position (Table 1) with temperature having a larger impact on both indices of proteolysis at the interior (P4) vs. the exterior (P1) position within the block (Figures 2 and 3).

Lipolysis-total FFA content. There was an effect $(P<0.01)$ of brine temperature (Table 3$)$ on the total FFA content of the cheese (Figure 4) with total FFA content increasing, increasing brine temperature. Position within block (Table 3$)$ also had an effect $(P<0.01)$ on total FFA content of the cheese (Figure 4) with a higher FFA content at the exterior position of the cheese (P1). The effect of brine temperature on FFA content within each position in the block cheese was stronger 
Table 1. Sums of the squares (Type III) and probability values (in parentheses) for the ANOVA of the impact of brine temperature $\left(12,15,18,21\right.$, and $\left.24^{\circ} \mathrm{C}\right)$ and position $(\mathrm{P} 1, \mathrm{P} 2, \mathrm{P} 3$, and $\mathrm{P} 4)$ on soluble nitrogen as a percentage of TN (pH 4.6 acetate buffer and 12\% TCA) content of block of Ragusano cheese at $24 \mathrm{~d}$ of brining.

\begin{tabular}{|c|c|c|c|c|c|}
\hline Factors & $\mathrm{df}$ & $\begin{array}{l}\mathrm{pH} 4.6 \text { acetate } \\
\text { buffer/TN } \\
(\%)\end{array}$ & $\begin{array}{l}12 \% \text { TCA/TN } \\
(\%)\end{array}$ & Analyzed as & Error term \\
\hline $\mathrm{T}^{1}$ & 4 & $\begin{array}{c}38.04^{*} \\
(<0.01)\end{array}$ & $\begin{array}{c}50.38^{*} \\
(<0.01)\end{array}$ & Category & Model error \\
\hline $\mathrm{W}^{2}$ & 2 & $\begin{array}{c}37.70^{*} \\
(<0.01)\end{array}$ & $\begin{aligned} 8.32 * \\
(<0.01)\end{aligned}$ & Category & Model error \\
\hline $\mathrm{P}^{3}$ & 3 & $\begin{array}{l}284.47^{*} \\
(<0.01)\end{array}$ & $\begin{array}{c}68.19^{*} \\
(<0.01)\end{array}$ & Category & Model error \\
\hline $\mathrm{T} \times \mathrm{W}$ & 8 & $\begin{array}{l}16.25^{*} \\
(0.05)\end{array}$ & $\begin{array}{l}4.94^{*} \\
(0.04)\end{array}$ & Interaction & Model error \\
\hline $\mathrm{T} \times \mathrm{P}$ & 12 & $\begin{array}{l}24.43^{*} \\
(0.04)\end{array}$ & $\begin{array}{l}15.97^{*} \\
(0.01)\end{array}$ & Interaction & Model error \\
\hline $\mathrm{W} \times \mathrm{P}$ & 6 & $\begin{array}{l}12.68 \\
(0.06)\end{array}$ & $\begin{array}{c}3.55 \\
(0.06)\end{array}$ & Interaction & Model error \\
\hline $\begin{array}{l}\text { Error } \\
\text { R-squared }\end{array}$ & 24 & $\begin{array}{r}21.21 \\
0.95\end{array}$ & $\begin{array}{l}5.91 \\
0.96\end{array}$ & & \\
\hline
\end{tabular}

*Statistically significant $(P<0.05)$.

${ }^{1} \mathrm{~T}=$ Temperature of brining.

${ }^{2} \mathrm{~W}=$ Week of cheese making.

${ }^{3} \mathrm{P}=$ Position within the block of cheese.

than the effect of position on total FFA content (Figure $4)$. There was a brine temperature $\times$ position $(P<0.01)$ interaction (Table 3 ), with brine temperature increasing lipolysis more at the exterior position (P1) than the interior position (Figure 4). There were significant linear and quadratic effects (Table 3) of time of brining on total FFA content of the cheese (Figure 5), and there was also a significant time of brining $\times$ temperature of brine (Table 3, Figure 5) with total FFA content increasing faster as a function of time with increasing brine temperature. There also was a significant time of brining $\times$ position interaction (Table 3 ) with position

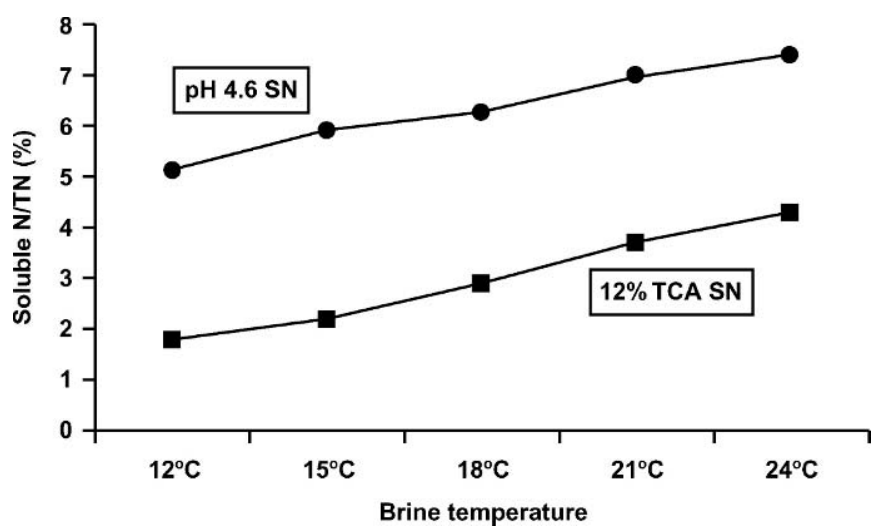

Figure 1. Mean (of all positions) nitrogen as a percentage of total

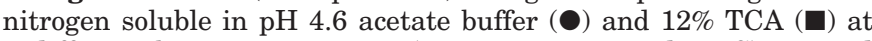
5 different brine temperature $\left(12,15,18,21\right.$, and $\left.24^{\circ} \mathrm{C}\right)$ at $24 \mathrm{~d}$ of brining.
1 (exterior of the block) increasing total FFA content faster during $24 \mathrm{~d}$ of brining than the other positions (Figure 6).

Lipolysis-individual FFA content. The least square means amount ( $\mathrm{mg} / 100 \mathrm{~g}$ of cheese) and the relative percentage of the total for each individual FFA is shown in Table 4 for positions $\mathrm{P} 2$ and $\mathrm{P} 4$ at 12 , 18 , and $24^{\circ} \mathrm{C}$ brine temperature averaged across four sampling times $(0,4,8$, and $24 \mathrm{~d})$. For all individual FFA and for the sum of the FFA, the concentration $(\mathrm{mg} / 100 \mathrm{~g}$ of cheese) increased with increasing brine temperature within both the $\mathrm{P} 2$ and $\mathrm{P} 4$ positions. The

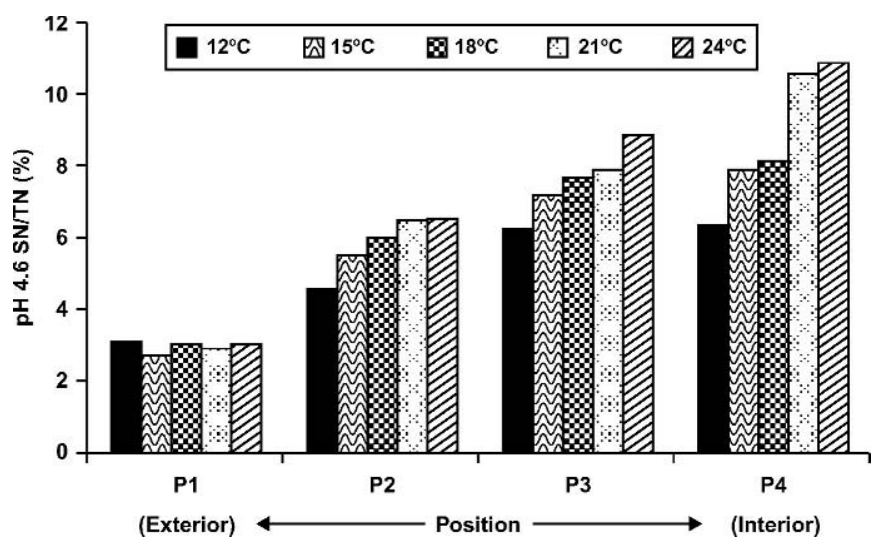

Figure 2. Mean nitrogen soluble in $\mathrm{pH} 4.6$ acetate buffer as a percentage of total nitrogen within the $\mathrm{P} 1, \mathrm{P} 2, \mathrm{P} 3$, and $\mathrm{P} 4$ positions of the block by brine temperature $\left(12,15,18,21\right.$, and $\left.24^{\circ} \mathrm{C}\right)$ at $24 \mathrm{~d}$ of brining. 


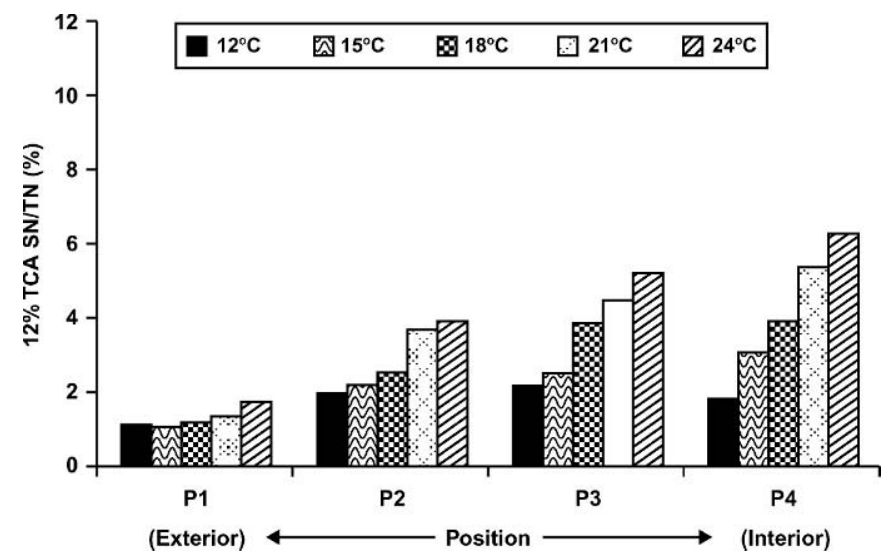

Figure 3. Mean soluble nitrogen in $12 \%$ TCA as a percentage of total nitrogen within the $\mathrm{P} 1, \mathrm{P} 2, \mathrm{P} 3$, and $\mathrm{P} 4$ positions of the block by brine temperature $\left(12,15,18,21\right.$, and $\left.24^{\circ} \mathrm{C}\right)$ at $24 \mathrm{~d}$ of brining.

increase in the sum of FFA concentrations (Table 4) with brine temperature (measured by GLC) is consistent with the increase in total FFA content, with temperature measured with the copper soap method (Figure 4). In position $\mathrm{P} 2$, the $\mathrm{C} 4$ and $\mathrm{C} 6$ relative percentage of total FFA increased with increasing brine temperature, while the relative percentage of all other FFA either remained the same or decreased with increasing brine temperature. Similar behavior was observed for position P4 (Table 4). In a review of the properties of pregastric lipases found in rennet pastes, Nelson et al. (1977) noted that pregastric lipase produces a preferential release of short-chain fatty acids from milk fat, particularly C4. There was a significant impact of brine temperature and time of brining $\times$ brine temperature interaction on both short- (C4 to $\mathrm{C} 10)$ and long- (C12 to C18:2) chain FFA (Table 5). The rate of increase of

Table 2. Least square means by position (across all temperature) and by brine temperature (across all position) of the soluble nitrogen as a percentage of TN (pH 4.6 acetate buffer and $12 \%$ TCA) content at $24 \mathrm{~d}$ of brining.

\begin{tabular}{lll}
\hline & $\begin{array}{c}\mathrm{pH} 4.6 \text { Acetate } \\
\text { buffer/TN }\end{array}$ & $12 \%$ \\
& & \\
\hline Position & & \\
P1 & $3.01^{\mathrm{d}}$ & $1.28^{\mathrm{d}}$ \\
$\mathrm{P} 2$ & $5.87^{\mathrm{c}}$ & $2.86^{\mathrm{c}}$ \\
$\mathrm{P} 3$ & $7.61^{\mathrm{b}}$ & $3.64^{\mathrm{b}}$ \\
$\mathrm{P} 4$ & $8.80^{\mathrm{a}}$ & $4.08^{\mathrm{a}}$ \\
Brine temperature & & \\
$12^{\circ} \mathrm{C}$ & $5.12^{\mathrm{d}}$ & $1.79^{\mathrm{e}}$ \\
$15^{\circ} \mathrm{C}$ & $5.88^{\mathrm{c}, \mathrm{d}}$ & $2.22^{\mathrm{d}}$ \\
$18^{\circ} \mathrm{C}$ & $6.25^{\mathrm{b}, \mathrm{c}}$ & $2.87^{\mathrm{c}}$ \\
$21^{\circ} \mathrm{C}$ & $6.98^{\mathrm{a}, \mathrm{b}}$ & $3.70^{\mathrm{b}}$ \\
$24^{\circ} \mathrm{C}$ & $7.37^{\mathrm{a}}$ & $4.27^{\mathrm{a}}$ \\
\hline \multicolumn{2}{c}{ a,b,c,d,e Least square means among positions or among brine tempera- } \\
tures within a column that do not share a common superscript are \\
different at $P<0.05$ level.
\end{tabular}

the short-chain FFA with time of brining and increasing brine temperature (Figure 7) was faster than the rate of increase of long-chain FFA with time of brining (Figure 8).

\section{DISCUSSION}

\section{Impact of Salt in Moisture on Proteolysis and Lipolysis}

Cheese undergoes a series of sequential changes during ripening caused by the action of enzymes from milk, rennet, and bacteria (both starter and nonstarter). In Ragusano cheese, these changes begin during brining. There was a strong impact of position within block on proteolysis and lipolysis, with proteolysis being high in the interior of the block and low at the surface (Figures 2 and 3), while lipolysis was the opposite with more lipolysis at the exterior of the block than the interior of the block (Figure 4). Chymosin plays a major role in the proteolysis of both $\alpha_{\mathrm{s}^{-}}$and $\beta$-CN during the early stages of ripening (Grappin et al., 1985). Proteolysis due to chymosin activity (Barbano et al., 1993) in presalted starter-free low-moisture part-skim Mozzarella cheese has been shown to survive stretching at $57^{\circ} \mathrm{C}$ and produce a normal level of $\mathrm{pH} 4.6$ acetate buffer SN. In rennet-free cheese made in the same study, the level of $\mathrm{pH} 4.6$ acetate buffer SN was very low. In a study of the impact of temperature of stretching on proteolysis in low-moisture part-skim Mozzarella cheese (Barbano et al., 1994a; Kindstedt et al., 1995), made using the stirred-curd, no-brine Mozzarella cheese making process (Barbano et al., 1994b), cheese temperatures during stretching of $62^{\circ} \mathrm{C}$ for $12 \mathrm{~min}$ and $64^{\circ} \mathrm{C}$ for $14 \mathrm{~min}$ had normal levels of proteolysis at $120 \mathrm{~d}$ of refrigerated storage, while at a cheese temperature of $66^{\circ} \mathrm{C}$ for 19 min, proteolysis and release of $\mathrm{pH} 4.6$ acetate buffer and $12 \%$ TCA SN were significantly reduced. Renda et al. (1997) also found normal levels of release of $\mathrm{pH} 4.6$ acetate SN in stirred-curd, no-brine Mozzarella when differences in Mozzarella mixer screw speed produced residence times of $26.6,16$, and $14.6 \mathrm{~min}$ at cheese temperatures of $55.5,52.5$, and $51.5^{\circ} \mathrm{C}$, respectively. These temperatures are higher than the cheese temperature $\left(48\right.$ to $49^{\circ} \mathrm{C}$ ) during the stretching of Ragusano cheese in the present study; therefore, it would be expected that chymosin and bacterial enzymes would be active in the cheese during aging. Salt concentration in cheese and more specifically salt concentration in the moisture of the cheese has a large impact on proteolysis during cheese aging (Thomas and Pearce, 1981), particularly proteolysis carried out by chymosin. As salt in the moisture content in Cheddar cheese increased from 
Table 3. Sums of the squares (Type III) and probability values (in parentheses) for the ANOVA of the impact of brine temperature $\left(12,15,18,21\right.$, and $\left.24^{\circ} \mathrm{C}\right)$ and position (P1, P2, P3, and P4) on total FFA content (mg/100 g cheese) of Ragusano cheese sampled at $0,1,4,8,16$, and $24 \mathrm{~d}$ of brining.

\begin{tabular}{|c|c|c|c|c|}
\hline Factors & $\mathrm{df}$ & FFA & Analyzed as & Error term \\
\hline \multicolumn{5}{|l|}{ Whole plot } \\
\hline $\mathrm{T}^{1}$ & 4 & $\begin{array}{r}223264^{*} \\
(<0.01)\end{array}$ & Category & $\mathrm{T} \times \mathrm{W} \times \mathrm{P}$ \\
\hline $\mathrm{W}^{2}$ & 2 & $\begin{array}{c}176169^{*} \\
\quad(<0.01)\end{array}$ & Category & $\mathrm{T} \times \mathrm{W} \times \mathrm{P}$ \\
\hline $\mathrm{P}^{3}$ & 3 & $\begin{array}{c}76970^{*} \\
(<0.01)\end{array}$ & Category & $\mathrm{T} \times \mathrm{W} \times \mathrm{P}$ \\
\hline $\mathrm{T} \times \mathrm{W}$ & 8 & $\begin{array}{l}24111^{*} \\
\quad(<0.01)\end{array}$ & Interaction & $\mathrm{T} \times \mathrm{W} \times \mathrm{P}$ \\
\hline $\mathrm{T} \times \mathrm{P}$ & 12 & $\begin{array}{l}18757^{*} \\
\quad(<0.01)\end{array}$ & Interaction & $\mathrm{T} \times \mathrm{W} \times \mathrm{P}$ \\
\hline $\mathrm{W} \times \mathrm{P}$ & 6 & $\begin{array}{l}3479^{*} \\
(0.04)\end{array}$ & Interaction & $\mathrm{T} \times \mathrm{W} \times \mathrm{P}$ \\
\hline $\mathrm{T} \times \mathrm{W} \times \mathrm{P}$ & 24 & $\begin{array}{l}5405 \\
\quad(0.92)\end{array}$ & Whole plot error & Model error \\
\hline \multicolumn{5}{|l|}{ Subplot } \\
\hline & 1 & $\begin{array}{l}317933^{*} \\
\quad(<0.01)\end{array}$ & Continuous & Model error \\
\hline $\mathrm{t} \times \mathrm{T}$ & 4 & $\begin{array}{l}149939^{*} \\
(<0.01)\end{array}$ & Interaction & Model error \\
\hline $\mathrm{t} \times \mathrm{W}$ & 2 & $\begin{array}{l}50030^{*} \\
\quad(<0.01)\end{array}$ & Interaction & Model error \\
\hline $\mathrm{t} \times \mathrm{P}$ & 3 & $\begin{array}{l}13858^{*} \\
\quad(<0.01)\end{array}$ & Interaction & Model error \\
\hline $\mathrm{t} \times \mathrm{T} \times \mathrm{P}$ & 12 & $\begin{array}{l}9120^{*} \\
(0.02)\end{array}$ & Interaction & Model error \\
\hline $\mathrm{t} \times \mathrm{t}$ & 1 & $\begin{array}{l}3733^{*} \\
(0.01)\end{array}$ & Interaction & Model error \\
\hline Error & 277 & 92894 & & \\
\hline R-squared & & 0.90 & & \\
\hline
\end{tabular}

*Statistically significant $(P<0.05)$.

${ }^{1} \mathrm{~T}=$ Temperature of brining.

${ }^{2} \mathrm{~W}=$ Week of cheese making.

${ }^{3} \mathrm{P}=$ Position within the cheese.

${ }^{4} \mathrm{t}=$ Time of brining.

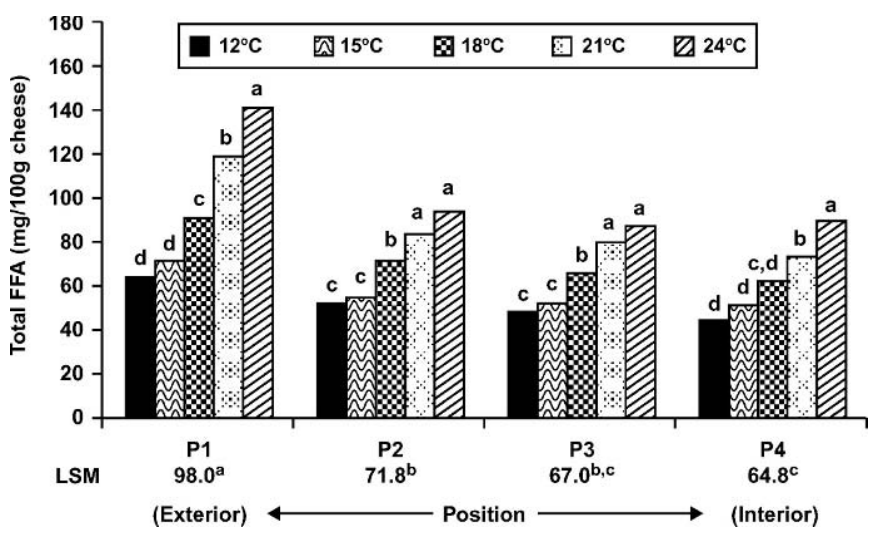

Figure 4. Mean total FFA content $(\mathrm{mg} / 100 \mathrm{~g}$ of cheese) within the P1, P2, P3, and P4 positions of the block by brine temperature $\left(12,15,18,21\right.$, and $\left.24^{\circ} \mathrm{C}\right)$ averaged across brining time $(0,1,4,8$, 16 , and $24 \mathrm{~d}$ ). Least square means (LSM) by position shown. LSM not sharing a common superscript are different $(P<0.05)$. Bars in the histogram within position not sharing a common letter are different $(P$ $<0.05)$.

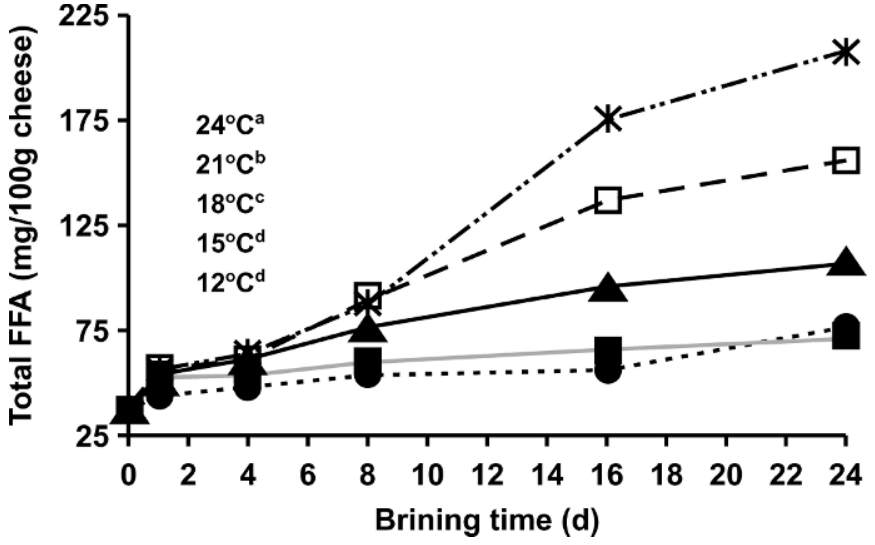

Figure 5. Mean total FFA (mg/100 g of cheese) averaged across all positions (P1, P2, P3, and P4) by brine temperature of $12(\bullet), 15$ $(\square), 18(\mathbf{\Lambda}), 21(\square)$, and $24^{\circ} \mathrm{C}(*)$ as a function of day of brining. Brine temperatures not sharing a common letter are different $(P<0.05)$. 


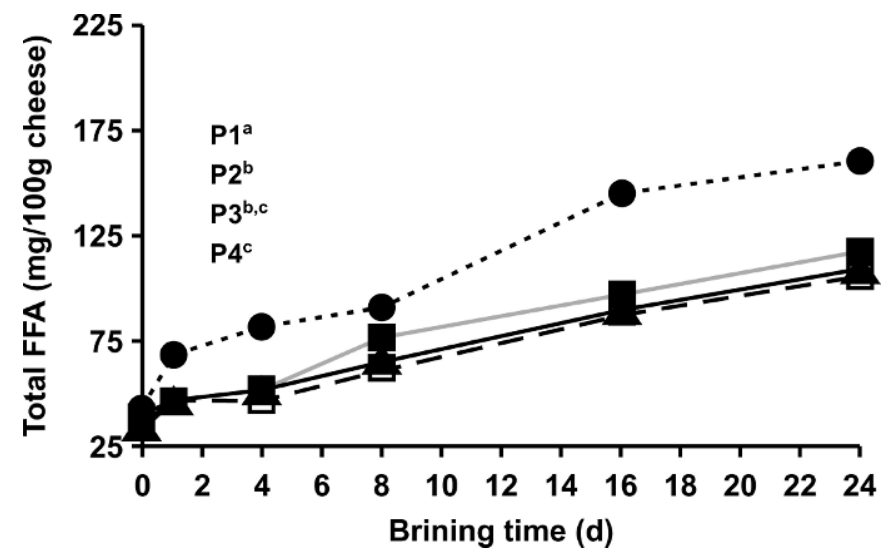

Figure 6. Total FFA (mg/100 g of cheese) content averaged across 5 different brine temperatures $\left(12,15,18,21\right.$, and $\left.24^{\circ} \mathrm{C}\right)$, within the

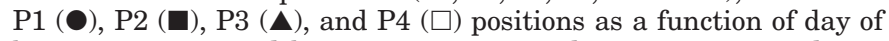
brining in saturated brine. Positions not sharing a common letter are different $(P<0.05)$.

4 to $8 \%$, the percentage of intact $\beta$-CN remaining after $28 \mathrm{~d}$, increased from about 55 to over $90 \%$ and $\alpha_{\mathrm{s}} \mathrm{-CN}$ increased from about 5 to $45 \%$ remaining intact
(Thomas and Pearce, 1981). In general, proteolysis decreases with increasing salt content in cheese.

Lipolysis in Italian cheese varieties, and specifically for Ragusano cheese, is carried out by pregastric esterase that is present in the rennet paste used in cheese manufacture (Nelson et al., 1977). However, in different cheese varieties the source of lipase can be different. In addition to pregastric lipase, native milk lipase and microbial lipases can also play a role in lipolysis in cheese. These different sources of lipase may be influenced differently by salt concentration. The impact of salt concentration on lipolysis during cheese aging has not been as clearly documented in the literature as the impact of salt on proteolysis.

Salt in moisture. There is a large gradient (15.6 to $7.75 \%$, respectively) of salt in moisture from the exterior to the interior position of aged Ragusano cheese (Licitra et al., 2000), and the magnitude of the gradient is influenced by the concentration of salt in the brine (Melilli et al., 2003a), with brines of lower concentration producing a larger gradient and higher mean salt content in the cheese in the same length of brining time. Increasing brine temperature also increased the rate of salt

Table 4. Least square means for ANOVA to determine the impact of brine temperature on FFA (content in mg FFA/100 g of cheese and weight percent $\mathrm{g} / 100 \mathrm{~g}$ of FFA) in the position P2 and P4 averaged for the total period $0,4,8$, and $24 \mathrm{~d}$.

\begin{tabular}{|c|c|c|c|c|c|c|c|}
\hline \multicolumn{4}{|c|}{ Position P2 } & \multicolumn{4}{|c|}{ Position P4 } \\
\hline \multirow[t]{2}{*}{ Fatty acid } & $12^{\circ} \mathrm{C}$ & $18^{\circ} \mathrm{C}$ & $24^{\circ} \mathrm{C}$ & Fatty acid & $12^{\circ} \mathrm{C}$ & $18^{\circ} \mathrm{C}$ & $24^{\circ} \mathrm{C}$ \\
\hline & \multicolumn{3}{|c|}{$-\mathrm{mg} / 100 \mathrm{~g}$ of cheese -} & & \multicolumn{3}{|c|}{$\mathrm{mg} / 100 \mathrm{~g}$ of cheese } \\
\hline $\mathrm{C} 4$ & $5.96^{\mathrm{c}}$ & $12.67^{\mathrm{b}}$ & $22.41^{\mathrm{a}}$ & $\mathrm{C} 4$ & $5.05^{\mathrm{b}}$ & $13.35^{\mathrm{b}}$ & $39.05^{\mathrm{a}}$ \\
\hline $\mathrm{C} 6$ & $2.07^{\mathrm{c}}$ & $4.15^{\mathrm{b}}$ & $6.80^{\mathrm{a}}$ & $\mathrm{C} 6$ & $1.93^{\mathrm{b}}$ & $3.44^{\mathrm{b}}$ & $7.18^{\mathrm{a}}$ \\
\hline $\mathrm{C} 8$ & $1.00^{\mathrm{c}}$ & $1.71^{\mathrm{b}}$ & $2.65^{\mathrm{a}}$ & $\mathrm{C} 8$ & $0.92^{\mathrm{b}}$ & $1.51^{\mathrm{b}}$ & $2.63^{\mathrm{a}}$ \\
\hline C10 & $2.44^{\mathrm{c}}$ & $3.67^{\mathrm{b}}$ & $4.91^{\mathrm{a}}$ & C10 & $2.52^{\mathrm{b}}$ & $3.21^{\mathrm{b}}$ & $4.75^{\mathrm{a}}$ \\
\hline $\mathrm{C} 12$ & $2.82^{\mathrm{c}}$ & $3.66^{\mathrm{b}}$ & $4.53^{\mathrm{a}}$ & C12 & $2.65^{\mathrm{c}}$ & $3.35^{\mathrm{b}}$ & $4.29^{\mathrm{a}}$ \\
\hline C14 & $6.15^{\mathrm{c}}$ & $7.91^{\mathrm{b}}$ & $9.91^{\mathrm{a}}$ & C14 & $5.93^{\mathrm{c}}$ & $7.28^{\mathrm{b}}$ & $8.91^{\mathrm{a}}$ \\
\hline C14:1 & 0.73 & 0.90 & 1.02 & $\mathrm{C} 14: 1$ & $0.67^{\mathrm{b}}$ & $0.81^{\mathrm{b}}$ & $1.07^{\mathrm{a}}$ \\
\hline C16 & $16.17^{\mathrm{c}}$ & $20.18^{\mathrm{b}}$ & $24.13^{\mathrm{a}}$ & C16 & $15.70^{\mathrm{c}}$ & $18.71^{\mathrm{b}}$ & $21.80^{\mathrm{a}}$ \\
\hline $\mathrm{C} 16: 1$ & $1.38^{\mathrm{b}}$ & $1.57^{\mathrm{a}, \mathrm{b}}$ & $1.82^{\mathrm{a}}$ & $\mathrm{C} 16: 1$ & 1.42 & 1.52 & 1.80 \\
\hline C18 & $4.27^{\mathrm{b}}$ & $5.18^{\mathrm{a}}$ & $5.86^{\mathrm{a}}$ & C18 & $4.20^{\mathrm{b}}$ & $4.73^{\mathrm{a}, \mathrm{b}}$ & $5.29^{\mathrm{a}}$ \\
\hline C18:1 & $14.50^{\mathrm{b}}$ & $16.42^{\mathrm{a}, \mathrm{b}}$ & $18.15^{\mathrm{a}}$ & C18:1 & $14.26^{\mathrm{b}}$ & $15.69^{\mathrm{b}}$ & $18.58^{\mathrm{a}}$ \\
\hline C18:2 & $3.64^{\mathrm{b}}$ & $4.13^{\mathrm{a}, \mathrm{b}}$ & $4.52^{\mathrm{a}}$ & C18:2 & $3.40^{\mathrm{b}}$ & $3.87^{\mathrm{ab}}$ & $4.31 \mathrm{va}$ \\
\hline Total & $61.13^{\mathrm{c}}$ & $82.16^{\mathrm{b}}$ & $106.73^{\mathrm{a}}$ & Total & $56.83^{\mathrm{b}}$ & $77.48^{\mathrm{b}}$ & $119.68^{\mathrm{a}}$ \\
\hline $\mathrm{C} 4$ & $9.95^{\mathrm{b}}$ & $12.91^{\mathrm{a}, \mathrm{b}}$ & $16.79^{\mathrm{a}}$ & $\mathrm{C} 4$ & $9.37^{\mathrm{c}}$ & $13.82^{\mathrm{b}}$ & $20.60^{\mathrm{a}}$ \\
\hline $\mathrm{C} 6$ & $3.42^{\mathrm{b}}$ & $4.41^{\mathrm{a}, \mathrm{b}}$ & $5.08^{\mathrm{a}}$ & C6 & 3.51 & 4.06 & 4.73 \\
\hline $\mathrm{C} 8$ & 1.65 & 1.92 & 2.11 & $\mathrm{C} 8$ & 1.66 & 1.82 & 1.92 \\
\hline $\mathrm{C} 10$ & 4.08 & 4.33 & 4.29 & C10 & 4.57 & 4.09 & 3.93 \\
\hline C12 & 4.71 & 4.57 & 4.47 & C12 & 4.8 & 4.45 & 4.11 \\
\hline $\mathrm{C} 14$ & 10.05 & 9.82 & 9.52 & C14 & $10.53^{\mathrm{a}}$ & $9.67^{\mathrm{a}}$ & $8.78^{\mathrm{b}}$ \\
\hline C14:1 & $1.17^{\mathrm{a}}$ & $1.11^{\mathrm{a}}$ & $1.02^{\mathrm{b}}$ & C14:1 & $1.18^{\mathrm{a}}$ & $1.06^{\mathrm{b}}$ & $1.01^{\mathrm{b}}$ \\
\hline $\mathrm{C} 16$ & 26.42 & 25.63 & 24.23 & $\mathrm{C} 16$ & $27.75^{\mathrm{a}}$ & $25.43^{\mathrm{a}, \mathrm{b}}$ & $22.89^{b}$ \\
\hline C16:1 & 2.21 & 2.01 & 1.96 & C16:1 & $2.45^{\mathrm{a}}$ & $2.06^{\mathrm{b}}$ & $1.90^{\mathrm{b}}$ \\
\hline C18 & 7.00 & 6.72 & 6.21 & C18 & $7.41^{\mathrm{a}}$ & $6.60^{\mathrm{a}, \mathrm{b}}$ & $5.91^{\mathrm{b}}$ \\
\hline C18:1 & $23.42^{\mathrm{a}}$ & $21.11^{\mathrm{b}}$ & $19.31^{\mathrm{b}}$ & C18:1 & $24.93^{\mathrm{a}}$ & $21.53^{\mathrm{b}}$ & $19.38^{b}$ \\
\hline C18:2 & $5.91^{\mathrm{a}}$ & $5.45^{\mathrm{a}, \mathrm{b}}$ & $4.99^{\mathrm{b}}$ & C18:2 & $5.98^{\mathrm{a}}$ & $5.41^{\mathrm{a}, \mathrm{b}}$ & $4.83^{\mathrm{b}}$ \\
\hline
\end{tabular}

${ }^{\mathrm{a}, \mathrm{b}, \mathrm{c}}$ Least square means within position and within row that do not share a common superscript are different at $P<0.05$ level. 
MELILLI ET AL.

Table 5. Sums of the squares (Type III) and probability values (in parentheses) for the ANOVA of the impact of brine temperature $\left(12,18\right.$, and $\left.24^{\circ} \mathrm{C}\right)$, positions of the cheese (P2 and $\left.\mathrm{P} 4\right)$ and time $(0,4,8$, and $24 \mathrm{~d}$ ) of brining on the sum of C4 to C10 and the sum of C12 to C18:2 FFA (mg/100 g of cheese).

\begin{tabular}{|c|c|c|c|c|c|}
\hline Factors & $\mathrm{df}$ & $\mathrm{C} 4$ to $\mathrm{C} 10$ & C12 to C18:2 & Analyzed as & Error term \\
\hline \multicolumn{6}{|l|}{ Whole plot } \\
\hline $\mathrm{T}^{1}$ & 2 & $\begin{array}{l}27830^{*} \\
(<0.01)\end{array}$ & $\begin{array}{l}7800 * \\
\quad(<0.01)\end{array}$ & Category & $\mathrm{T} \times \mathrm{P} \times \mathrm{W}$ \\
\hline $\mathrm{P}^{2}$ & 1 & $\begin{array}{l}932^{*} \\
(<0.01)\end{array}$ & $\begin{array}{r}174^{*} \\
(0.01)\end{array}$ & Category & $\mathrm{T} \times \mathrm{P} \times \mathrm{W}$ \\
\hline $\mathrm{W}^{3}$ & 2 & $\begin{array}{l}4561^{*} \\
(<0.01)\end{array}$ & $\begin{array}{c}14071^{*} \\
(<0.01)\end{array}$ & Category & $\mathrm{T} \times \mathrm{P} \times \mathrm{W}$ \\
\hline $\mathrm{T} \times \mathrm{P}$ & 2 & $\begin{array}{l}1254^{*} \\
(<0.01)\end{array}$ & NS & Interaction & $\mathrm{T} \times \mathrm{P} \times \mathrm{W}$ \\
\hline $\mathrm{T} \times \mathrm{W}$ & 4 & $\begin{array}{l}1952^{*} \\
(0.01)\end{array}$ & $\begin{array}{l}513^{*} \\
(0.01)\end{array}$ & Interaction & $\mathrm{T} \times \mathrm{P} \times \mathrm{W}$ \\
\hline $\mathrm{T} \times \mathrm{P} \times \mathrm{W}$ & 6 & $\begin{array}{c}333 \\
(0.98)\end{array}$ & $\mathrm{NA}^{4}$ & Whole plot error & Model error \\
\hline $\mathrm{T} \times \mathrm{P} \times \mathrm{W}$ & 8 & NA & $\begin{array}{r}117 \\
(0.99)\end{array}$ & Whole plot error & Model error \\
\hline \multicolumn{6}{|l|}{ Subplot } \\
\hline$t^{5}$ & 1 & $\begin{array}{l}43143^{*} \\
\quad(<0.01)\end{array}$ & $\begin{array}{l}14737^{*} \\
\quad(<0.01)\end{array}$ & Continuous & Model error \\
\hline $\mathrm{t} \times \mathrm{T}$ & 2 & $\begin{array}{l}27357^{*} \\
\quad(<0.01)\end{array}$ & $\begin{array}{l}6989^{*} \\
\quad(<0.01)\end{array}$ & Interaction & Model error \\
\hline $\mathrm{t} \times \mathrm{W}$ & 2 & $\begin{array}{l}4546^{*} \\
(<0.01)\end{array}$ & $\begin{array}{l}3501^{*} \\
(<0.01)\end{array}$ & Interaction & Model error \\
\hline Error & 48 & 14733 & NA & & \\
\hline Error & 49 & NA & 5548 & & \\
\hline $\mathrm{R}$-squared & & 0.87 & 0.88 & & \\
\hline
\end{tabular}

*Statistically significant $(P<0.05)$.

${ }^{1} \mathrm{~T}=$ Temperature of brining.

${ }^{2} \mathrm{P}=$ Position $\mathrm{P} 2$ and $\mathrm{P} 4$ of the cheese.

${ }^{3} \mathrm{~W}=$ Week of cheese making.

${ }^{4} \mathrm{NA}=$ Not applicable.

${ }^{5} \mathrm{t}=$ Time of brining.

uptake by blocks of Ragusano cheese (Melilli et al., $2003 \mathrm{~b})$. In the present study of Ragusano cheese, there was an impact $(P \leq 0.01)$ of brine temperature on salt in the moisture content of Ragusano cheese (Table 6)

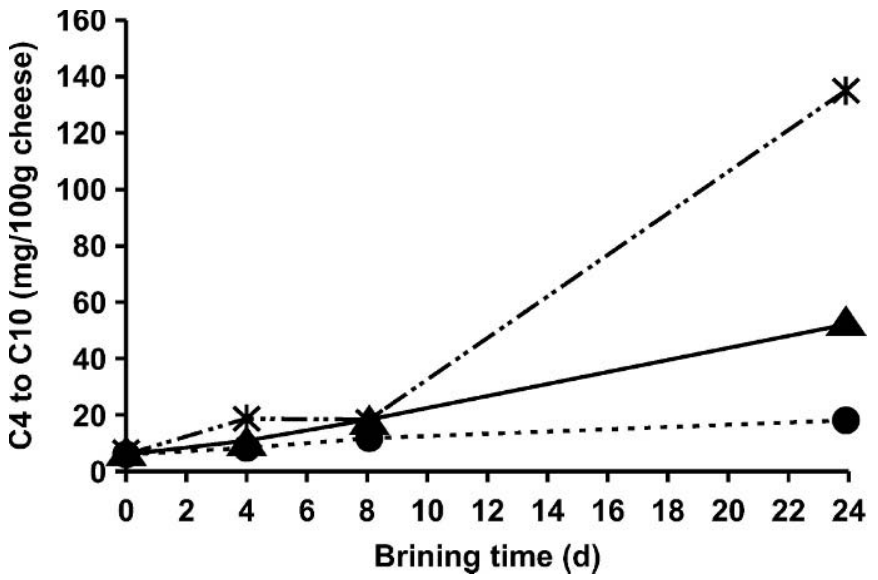

Figure 7. Sum of single FFA (mg/100 g of cheese) from $\mathrm{C} 4$ to $\mathrm{C} 10$ by brine temperatures of $12(\bullet), 18(\mathbf{\Delta})$, and $24^{\circ} \mathrm{C}(*)$ as a function of day of brining in saturated brine. with higher brine temperature producing higher salt in moisture in the cheese (Table 7) and more penetration of salt into the cheese. The reason for the impact of brine temperature on salt penetration is due to the impact of brine temperature on the viscosity of the water phase

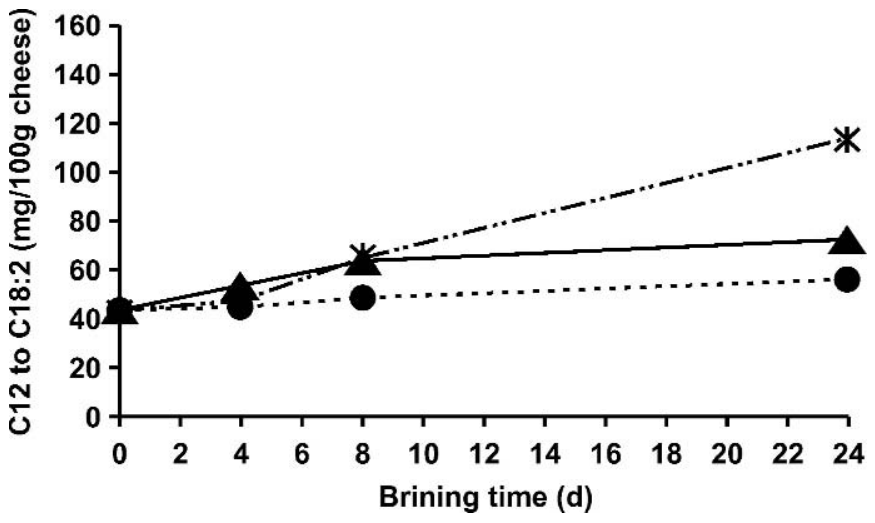

Figure 8. Sum of single FFA (mg/100 g of cheese) from C12 to C18:2 by brine temperatures of $12(\mathbf{)}), 18(\mathbf{\Delta})$, and $24^{\circ} \mathrm{C}(*)$ as a function of day of brining in saturated brine. 
Table 6. Sums of the squares (Type III) and probability values (in parentheses) for the ANOVA of the impact of brine temperature $\left(12,15,18,21\right.$, and $\left.24^{\circ} \mathrm{C}\right)$ on salt in moisture content of cheese positions (P1, P2, P3, and P4) of Ragusano cheese at $0,1,4,8,16$, and $24 \mathrm{~d}$ of brining.

\begin{tabular}{|c|c|c|c|c|c|c|c|}
\hline Factors & $\mathrm{df}$ & $\mathrm{P} 1$ & $\mathrm{P} 2$ & P3 & $\mathrm{P} 4$ & Analyzed as & Error term \\
\hline \multicolumn{8}{|l|}{ Whole plot } \\
\hline $\mathrm{T}^{1}$ & 4 & $\begin{array}{c}54.01 * \\
(0.01)\end{array}$ & $\begin{array}{c}40.09^{*} \\
(<0.01)\end{array}$ & $\begin{array}{c}37.74^{*} \\
(<0.01)\end{array}$ & $\begin{array}{r}8.68^{*} \\
(<0.01)\end{array}$ & Category & $\mathrm{T} \times \mathrm{W}$ \\
\hline $\mathrm{W}^{2}$ & 2 & $\underset{(<0.01)}{10.91 *}$ & $\begin{array}{r}6.58^{*} \\
(<0.01)\end{array}$ & $\begin{array}{r}3.20^{*} \\
(<0.01)\end{array}$ & $\begin{array}{c}1.07^{*} \\
(0.01)\end{array}$ & Category & $\mathrm{T} \times \mathrm{W}$ \\
\hline $\mathrm{T} \times \mathrm{W}$ & 8 & $\begin{array}{c}4.57 \\
(0.99)\end{array}$ & $\begin{array}{c}1.54 \\
(0.48)\end{array}$ & $\begin{array}{c}0.73 \\
(0.76)\end{array}$ & $\begin{array}{c}0.33 \\
(0.16)\end{array}$ & Interaction & Model error \\
\hline $\begin{array}{l}\text { Subplot } \\
t^{3}\end{array}$ & 1 & $\begin{array}{c}2625.87^{*} \\
(<0.01)\end{array}$ & $\begin{array}{c}1135.01^{*} \\
(<0.01)\end{array}$ & $\begin{array}{c}455.67^{*} \\
(<0.01)\end{array}$ & $\begin{array}{c}95.12^{*} \\
(<0.01)\end{array}$ & Continuous & Model error \\
\hline $\mathrm{t} \times \mathrm{T}$ & 4 & NS4 & $\begin{array}{c}14.39 * \\
(<0.01)\end{array}$ & $\begin{array}{l}18.22 * \\
(<0.01)\end{array}$ & $\begin{array}{c}5.93^{*} \\
(<0.01)\end{array}$ & Interaction & Model error \\
\hline $\mathrm{t} \times \mathrm{t}$ & 1 & $\begin{array}{c}411.60 * \\
(<0.01)\end{array}$ & $\begin{array}{c}35.34^{*} \\
(<0.01)\end{array}$ & NS & $\begin{array}{r}3.90 * \\
(<0.01)\end{array}$ & Interaction & Model error \\
\hline $\mathrm{t} \times \mathrm{t} \times \mathrm{T}$ & 4 & NS & $\begin{array}{r}5.77^{*} \\
(<0.01)\end{array}$ & NS & NS & Interaction & Model error \\
\hline Error & 73 & 202.22 & $\ldots$ & $\ldots$ & $\ldots$ & & \\
\hline Error & 65 & $\ldots$ & 13.10 & $\ldots$ & $\ldots$ & & \\
\hline Error & 70 & $\ldots$ & $\ldots$ & 10.26 & $\ldots$ & & \\
\hline Error & 69 & $\ldots$ & $\ldots$ & & 1.88 & & \\
\hline $\mathrm{R}$-squared & & 0.95 & 0.99 & 0.98 & 0.98 & & \\
\hline
\end{tabular}

*Statistically significant $(P<0.05)$.

${ }^{1} \mathrm{~T}=$ Temperature of brining.

${ }^{2} \mathrm{~W}=$ Week of cheese making.

${ }^{3} \mathrm{t}=$ Time of brining.

of cheese, as reported previously (Melilli et al., 2003b). At high brine temperature (e.g., $24^{\circ} \mathrm{C}$ ), the viscosity of the water phase of cheese would be lower than at low brine temperature (e.g., $\left.12^{\circ} \mathrm{C}\right)$. The salt in moisture at the exterior of the blocks after $24 \mathrm{~d}$ of brining (Table 7) ranged from 9.3 to $11.0 \%$, while in the center of the blocks the salt in moisture was very low, 0.61 to $1.24 \%$.

Proteolysis. The wide range in salt in moisture content would explain the significant impact of position within the block on the extent of proteolysis measured as $\mathrm{pH} 4.6$ acetate buffer SN/TN and 12\% TCA SN/TN (Table 1, Figures 1 to 3). The data for both $\mathrm{pH} 4.6$ acetate buffer and $12 \%$ TCA SN/TN are plotted as a

Table 7. Impact of brine temperature $\left(12,15,18,21\right.$, and $\left.24^{\circ} \mathrm{C}\right)$ on the least square means of salt in moisture content (\%) for the $24 \mathrm{~d}$ brining period (mean of $0,1,4,8,16$, and $24 \mathrm{~d}$ ) of Ragusano cheese in position $\mathrm{P} 1, \mathrm{P} 2, \mathrm{P} 3$, and $\mathrm{P} 4$.

\begin{tabular}{lllll}
\hline \multirow{2}{*}{$\begin{array}{l}\text { Brine } \\
\text { temperature }\end{array}$} & \multicolumn{4}{c}{ Position } \\
\cline { 2 - 5 } & $\mathrm{P} 1^{1}$ & $\mathrm{P} 2$ & $\mathrm{P} 3$ & $\mathrm{P} 4^{1}$ \\
\hline $12^{\circ} \mathrm{C}$ & $9.32^{\mathrm{b}, \mathrm{c}}$ & $3.67^{\mathrm{c}}$ & $1.65^{\mathrm{c}}$ & $0.61^{\mathrm{d}}$ \\
$15^{\circ} \mathrm{C}$ & $8.88^{\mathrm{b}}$ & $3.51^{\mathrm{c}}$ & $1.77^{\mathrm{c}}$ & $0.66^{\mathrm{d}}$ \\
$18^{\circ} \mathrm{C}$ & $10.33^{\mathrm{a}, \mathrm{c}}$ & $4.57^{\mathrm{b}}$ & $2.39^{\mathrm{b}}$ & $0.89^{\mathrm{c}}$ \\
$21^{\circ} \mathrm{C}$ & $10.35^{\mathrm{a}, \mathrm{c}}$ & $4.67^{\mathrm{b}}$ & $2.52^{\mathrm{b}}$ & $1.05^{\mathrm{b}}$ \\
$24^{\circ} \mathrm{C}$ & $11.02^{\mathrm{a}}$ & $5.45^{\mathrm{a}}$ & $3.08^{\mathrm{a}}$ & $1.24^{\mathrm{a}}$ \\
\hline \multicolumn{4}{c}{$\mathrm{ab, \textrm {b } , \mathrm { d }}$ Least square means within the same column that do not share } \\
a common superscript are different at $P<0.05$. \\
\multicolumn{2}{l}{$\mathrm{P} 1$ = Exterior and $\mathrm{P} 4$ = interior position within the cheese. }
\end{tabular}

function of salt in moisture content of the cheese in Figure 9 . There was a significant impact of both brine temperature and salt in moisture on the amount of $\mathrm{pH}$ 4.6 acetate buffer SN/TN and $12 \%$ TCA SN/TN (Table 8), with both $\mathrm{pH} 4.6$ acetate buffer SN/TN and $12 \%$ TCA $\mathrm{SN} / \mathrm{TN}$ decreasing with increasing salt in the moisture content. The impact of increasing salt in moisture content on the reduction in $\mathrm{pH} 4.6$ acetate buffer SN/TN was larger than the impact of increasing salt in moisture on $12 \%$ TCA SN/TN. Increases in $\mathrm{pH} 4.6$ acetate

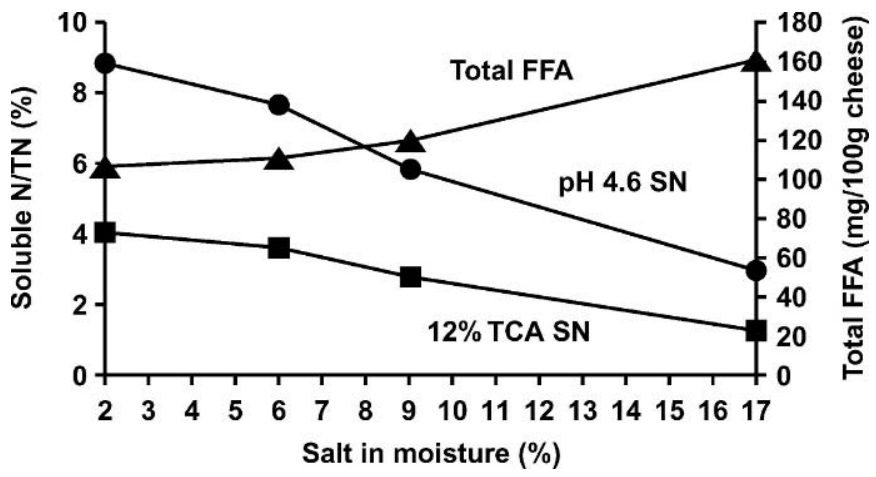

Figure 9. Impact of salt in moisture on $\mathrm{pH} 4.6$ acetate buffer ( and $12 \%$ TCA ( ) soluble nitrogen as a percentage of total nitrogen, and on total FFA (mg/100 g of cheese) ( $\mathbf{\Delta})$ averaged across 5 different brine temperatures $\left(12,15,18,21\right.$, and $\left.24^{\circ} \mathrm{C}\right)$ for cheese after $24 \mathrm{~d}$ of brining. 
Table 8. Sums of the squares (Type III) and probability values (in parentheses) for the ANOVA of the impact of brine temperature $\left(12,15,18,21\right.$, and $\left.24^{\circ} \mathrm{C}\right)$ and salt in moisture content $(\%)$ on soluble nitrogen as a percentage of TN ( $\mathrm{pH} 4.6$ acetate buffer and 12\% TCA) content of Ragusano cheese at $24 \mathrm{~d}$ brining.

\begin{tabular}{|c|c|c|c|c|c|}
\hline Factors & $\mathrm{df}$ & $\mathrm{pH} 4.6 / \mathrm{TN}$ & $12 \% \mathrm{TCA} / \mathrm{TN}$ & Analyzed as & Error term \\
\hline \multicolumn{6}{|l|}{ Whole plot } \\
\hline $\mathrm{T}^{1}$ & 4 & $\begin{array}{c}78.26^{*} \\
(<0.01)\end{array}$ & $\begin{array}{c}70.16^{*} \\
(<0.01)\end{array}$ & Category & $\mathrm{T} \times \mathrm{W}$ \\
\hline $\mathrm{W}^{2}$ & 2 & $\begin{array}{c}47.52^{*} \\
(<0.01)\end{array}$ & $\begin{array}{c}12.68^{*} \\
(<0.01)\end{array}$ & Category & $\mathrm{T} \times \mathrm{W}$ \\
\hline $\mathrm{T} \times \mathrm{W}$ & 8 & $\begin{array}{c}19.85^{*} \\
(0.01)\end{array}$ & $\begin{array}{c}6.19^{*} \\
(0.01)\end{array}$ & Whole plot error & Model error \\
\hline \multicolumn{6}{|l|}{ Subplot } \\
\hline $\mathrm{SM}^{3}$ & 1 & $\begin{array}{c}288.00 * \\
(<0.01)\end{array}$ & $\begin{array}{c}67.86^{*} \\
(<0.01)\end{array}$ & Continuous & Model error \\
\hline $\mathrm{SM} \times \mathrm{T}$ & 4 & $\begin{array}{l}26.57^{*} \\
(0.01)\end{array}$ & $\begin{array}{c}16.18^{*} \\
(<0.01)\end{array}$ & Interaction & Model error \\
\hline $\mathrm{SM} \times \mathrm{W}$ & 2 & $\begin{array}{c}5.25 \\
(0.06)\end{array}$ & $\begin{array}{c}2.15^{*} \\
(0.01)\end{array}$ & Interaction & Model error \\
\hline Error & 38 & 33.61 & 9.02 & & \\
\hline $\mathrm{R}$-squared & & 0.92 & 0.94 & & \\
\hline
\end{tabular}

*Statistically significant $(P<0.05)$.

${ }^{1} \mathrm{~T}=$ Temperature of brining.

${ }^{2} \mathrm{~W}=$ Week of cheese making.

${ }^{3} \mathrm{SM}=$ Salt in moisture content $(\%)$.

buffer SN/TN are primarily produced by the action of rennet (Rank et al., 1985), while the increases in $12 \%$ TCA SN/TN are the result of further proteolysis by rennet and peptidase activity from microorganisms (Rank et al., 1985). Thus, in the present study after 24 $\mathrm{d}$ of brining, the major impact of higher salt in moisture at the exterior position of the block was to limit proteolysis by chymosin. There was a significant interaction of brine temperature and salt in moisture content for both pH 4.6 acetate buffer SN/TN (Table 8, Figure 10) and $12 \%$ TCA SN/TN (Table 8, Figure 11). The lower the salt in moisture content in the cheese the larger the

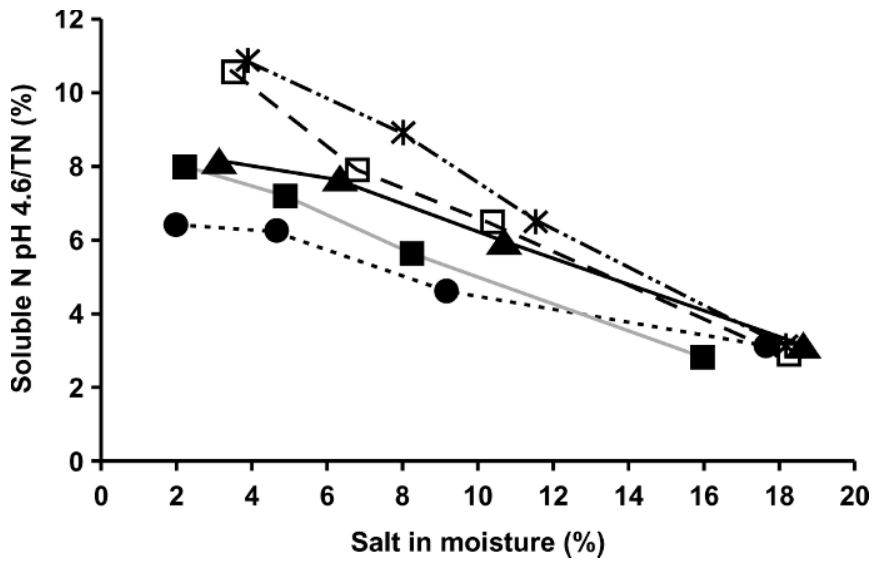

Figure 10. Effect of salt in moisture on the interaction brine temperature by position for $\mathrm{pH} 4.6$ acetate buffer soluble nitrogen as a percentage of total nitrogen at brine temperatures of $12(\mathbf{)}), 15$ (匹), $18(\boldsymbol{\Delta}), 21(\square)$, and $24^{\circ} \mathrm{C}(*)$. increase in proteolysis due to increasing brine temperature (Figures 10 and 11).

Lipolysis. Lipolysis within the blocks of cheese was also influenced by position within the block (Table 3, Figure 4), but in contrast to proteolysis, lipolysis in the cheese was highest at the exterior position of the block. Therefore, lipolysis increased with increasing salt in moisture (Figure 9). The data for total FFA content were analyzed as a function of salt in moisture instead of by position (Table 9). There was a significant effect (Table 9) of brine temperature, salt in moisture, and the 3-way interaction of salt in moisture by brine tem-

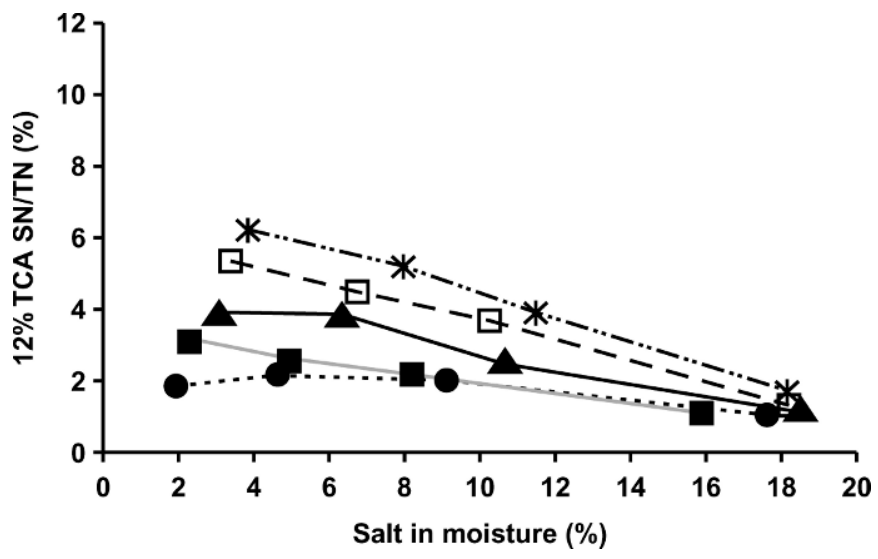

Figure 11. Effect of salt in moisture on the interaction brine temperature by position for $12 \%$ TCA soluble nitrogen as a percentage of total nitrogen at brine temperatures of $12(\boldsymbol{\bullet}), 15(\boldsymbol{\square}), 18(\mathbf{\Delta}), 21$ $(\square)$, and $24^{\circ} \mathrm{C}(*)$. 
Table 9. Sums of the squares (Type III) and probability values (in parentheses) for the ANOVA of the impact of brine temperature $\left(12,15,18,21\right.$, and $\left.24^{\circ} \mathrm{C}\right)$ and salt in moisture content (\%) on total FFA content (mg/100 $\mathrm{g}$ of cheese) of Ragusano cheese at $0,1,4,8,16$, and $24 \mathrm{~d}$ of brining.

\begin{tabular}{lrccll}
\hline Factors & df & Total FFA & $P$-value & Analyzed as & Error term \\
\hline Whole plot & & & & & \\
$\mathrm{T}^{1}$ & 4 & $49538^{*}$ & $(<0.01)$ & Category & $\mathrm{T} \times \mathrm{W}$ \\
$\mathrm{W}^{2}$ & 2 & $87068^{*}$ & $(<0.01)$ & Category & $\mathrm{T} \times \mathrm{W}$ \\
$\mathrm{T} \times \mathrm{W}$ & 8 & $8002^{*}$ & $(0.01)$ & Interaction & $\mathrm{T} \times \mathrm{W}$ \\
Subplot & & $71609^{*}$ & $(<0.01)$ & Continuous & $\mathrm{SM} \times \mathrm{T} \times \mathrm{W}$ \\
$\mathrm{SM}^{3}$ & 1 & $33258^{*}$ & $(<0.01)$ & Interaction & Model error \\
$\mathrm{SM} \times \mathrm{T} \times \mathrm{W}$ & 14 & & & \\
$\mathrm{Sub}$ subplot & 1 & $65604^{*}$ & $(<0.01)$ & Continuous & Model error \\
$\mathrm{t}^{4}$ & 4 & $32847^{*}$ & $(<0.01)$ & Interaction & Model error \\
$\mathrm{t} \times \mathrm{T}$ & 2 & $23666^{*}$ & $(<0.01)$ & Interaction & Model error \\
$\mathrm{t} \times \mathrm{W}$ & 5 & $4628^{*}$ & $(0.01)$ & Interaction & Model error \\
$\mathrm{SM} \times \mathrm{t} \times \mathrm{T}$ & 318 & 95584 & & & \\
Error & & 0.91 & & & \\
$\mathrm{R}$-squared & & & &
\end{tabular}

\footnotetext{
*Statistically significant $(P<0.05)$.

${ }^{1} \mathrm{~T}=$ Temperature of brining.

${ }^{2} \mathrm{~W}=$ Week of cheese making.

${ }^{3} \mathrm{SM}=$ Salt in moisture content (\%).

${ }^{4} \mathrm{t}=$ Time of brining.
}

perature by time of brining, as seen in Figure 12. The impact of brine temperature was large, while a gradual increase in total FFA content occurred at all brine temperatures with increasing salt in the moisture content of the cheese. The salt in moisture $\times$ temperature interaction can be seen in Figure 12 (i.e., the difference in the slopes of the lines as a function of increasing salt in moisture). The 3 -way interaction of position $\times$ brine temperature $\times$ time (Table 3 ) can be seen in Figure 13 . The slope of the relationship of increasing FFA content within $\mathrm{P} 1$ (exterior) going from $12^{\circ} \mathrm{C} \mathrm{d} 0$ to $24^{\circ} \mathrm{C} \mathrm{d} 24$, compared with the same slope for the data within P4 (interior) in Figure 13 is different, and this reflects the 3 -way interaction (salt in moisture $\times$ time $\times$ brine

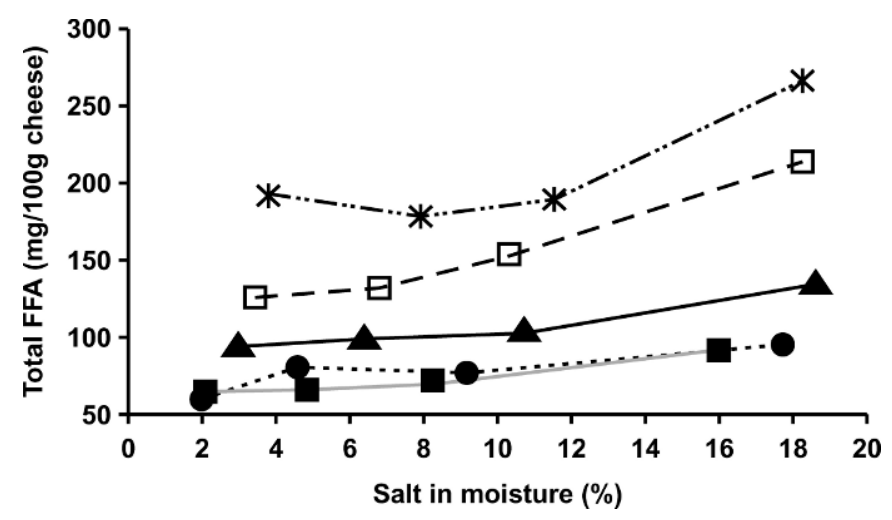

Figure 12. Effect of salt in moisture on the interaction of brine temperature by position on total FFA ( $\mathrm{mg} / 100 \mathrm{~g}$ of cheese) at brine temperatures of $12(\bullet), 15(\square), 18(\boldsymbol{\Delta}), 21(\square)$, and $24^{\circ} \mathrm{C}(*)$. temperature) that was significant in the ANOVA model (Table 9).

We did not expect that lipolysis would show the opposite relationship with salt in moisture as that commonly found for proteolysis in cheese, with FFA content being higher at higher salt in moisture. When the block of cheese was placed into the brine the FFA content of the cheese was low (about $50 \mathrm{mg} / 100 \mathrm{~g}$ of cheese) and uniform throughout. The concentration of $\mathrm{C} 4$ as a FFA in the cheese at this stage was about $2.9 \mathrm{mg} / 100 \mathrm{~g}$. The concentration of $\mathrm{C} 4$, as a FFA in the brine, was about

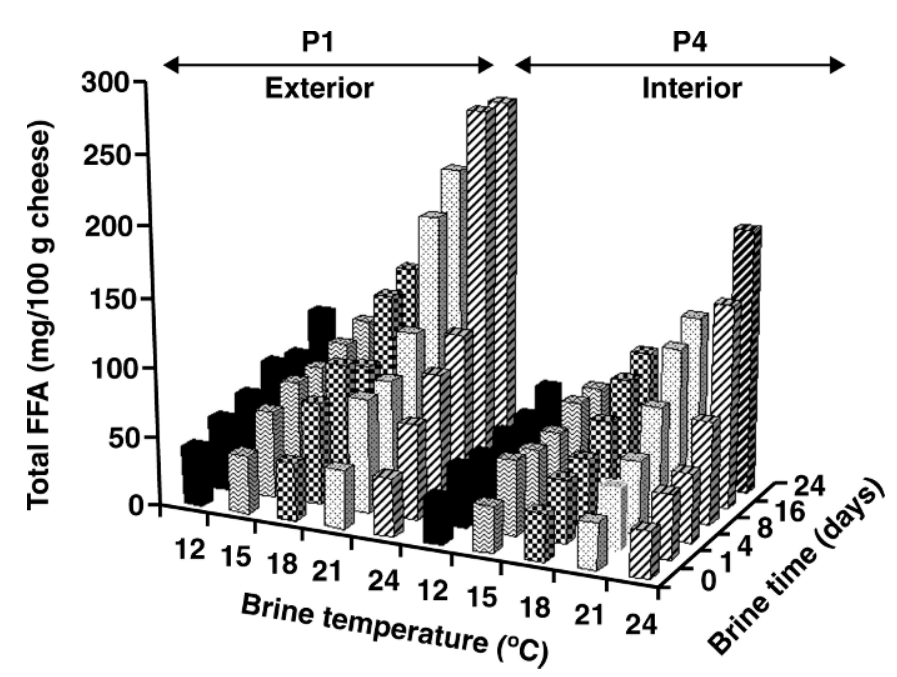

Figure 13. The influence of brine temperature $(12,15,18,21$, and $\left.24^{\circ} \mathrm{C}\right)$ and time of brining $(0,1,4,8,16$, and $24 \mathrm{~d})$ within position P1 and P4 on total FFA content (mg/100 g of cheese) of cheese. 
$9.4 \mathrm{mg} / 100 \mathrm{~g}$ of brine out of total FFA content in brine of about $12.8 \mathrm{mg} / 100 \mathrm{~g}$ of brine and represented about $73 \%$ of the FFA. Typically, brine used to salt cheese contains water-soluble components of the cheese such as lactic acid and calcium (Geurts et al., 1972, 1974) that are extracted from the cheese. For Ragusano cheese, it appears that there was some normal level of water-soluble FFA that was present in the brine. When the blocks of cheese were placed in the brine, the concentration of $\mathrm{C} 4$ in the brine was higher than in the cheese. Therefore, for the initial few days of brining, the FFA C4 may have actually increased at the surface of the cheese (P1) due to diffusion of $\mathrm{C} 4$ into the cheese from the brine. This is consistent with the higher level of FFA in the P1 position that was established by $\mathrm{d} 1$ of brining (Figure 6). Once inside the cheese, the C4 FFA may partition between the water phase and the fat phase depending on the fluidity of the fat, which will be influenced by brine temperature. Based on the results in the present study, the total C4 FFA concentration in the P2 portion of the cheese reached the concentration of that found in the brine between 8 and $12 \mathrm{~d}$ of brining. Thus, the P1 portion would reach that level sooner. Thus, during the first few days of brining it is likely that the C4 FFA concentration in the exterior portion of the cheese increases due to both entry of C4 from the brine and lipolysis that is taking place in the $\mathrm{P} 1$ portion. At the same time, and particularly during the first $4 \mathrm{~d}$, water-soluble short-chain FFA were being carried as solute in the water that traveled from the interior of the block to the exterior of the block as the block loses moisture (Melilli et al., 2003b) during the $24 \mathrm{~d}$ of brining. At the beginning of brining, a 3.8$\mathrm{kg}$ block contains approximately $1650 \mathrm{~g}$ of water and at the end of brining the block contains about $1150 \mathrm{~g}$ of water. All of the water lost from the block exits the block by passing through the P1 (exterior) position of the block. All water-soluble components would be carried in that water and there could be some accumulation of these components near the surface of the block. The blocks brined at higher temperature had higher moisture loss during brining and had higher FFA content near the surface. Lee et al. (1980) found that both salt and butanoic acid diffused freely in the water phase of Mozzarella cheese, while as FFA chain length increased, they found the diffusion rate for octanoic acid was much slower than butanoic acid. The extent of partitioning that would take place in $\mathrm{P} 1$ of $\mathrm{C} 4 \mathrm{FFA}$ between the fat phase of the cheese and water phase of the cheese is not known. Thus, C4 FFA could be contributed in the $\mathrm{P} 1$ portion by both the water-soluble $\mathrm{C} 4$ entering the cheese from the brine and the watersoluble C4 moving from the central portions of the cheese to the surface during the migration of water from the interior to the exterior portion of the cheese during the early stages of brine salting.

At the same time, the higher salt at the exterior of the block could have had a direct impact of increasing the rate of lipolysis. In the case of Ragusano cheese, the added lipase is pregastric lipase. Native milk lipase may also be active in this cheese because it was made from raw milk. Increased concentration of calcium salts of chloride and lactates are known to increase the rate of reaction of many lipases (Bier, 1955). We do not know if the calcium concentration in the aqueous phase of our cheese near the surface of the blocks was higher than in the interior of the blocks. Kindstedt et al. (1992) proposed that added salt promotes calcium to move from the cheese matrix into the water phase of the cheese for brine-salted Mozzarella ( $\mathrm{pH} 5.11$ to 5.26 while cheese is cooling the brine after stretching), while Pastorino et al. (2003) found no increased dissociation of calcium from the matrix when Muenster cheese $\mathrm{pH}$ 5.45) was injected with salt brine (after being held at $4^{\circ} \mathrm{C}$ for $14 \mathrm{~d}$ ). The cheese $\mathrm{pH}$ may also influence and interact with salt concentration, cheese temperature, and cheese age to modify the impact that added salt may have on dissociation of calcium from the casein matrix in cheese. The level of salt in the moisture in brine-salted cheeses near the surface in the present study was very high, and it is possible under these conditions that some dissociation of both calcium and casein from the protein matrix into the water phase of the cheese could have occurred.

The influence of calcium salts on lipolysis is either by forming insoluble salts of FFA as they are released by lipase or by their effect on the ability of the enzyme to interact with the hydrophobic substrate at a lipid/ water interface (Bier, 1955). In the cheese during brining, as the salt $(\mathrm{NaCl})$ penetrated the pores of the cheese, there may have been an exchange of sodium for calcium that was bound to the protein matrix. This exchange would be the greatest in areas of highest $\mathrm{NaCl}$ concentration (i.e., near the surface of the block cheese), and this would occur very early in the brine salting. Thus, the level of $\mathrm{CaCl}_{2}$ and calcium lactate may be higher near the surface of the cheese and could favor a faster rate of lipolysis. The higher level of FFA in the P1 position was established by d 1 of brining (Figure 6) and then increased with time of brine salting (significant time $\times$ position interaction, Table 3 ) faster than the other positions.

\section{Does Lipolysis Increase with Increasing Salt in Moisture?}

To try to directly answer this question, independent of the possibility of migration of FFA from the center 


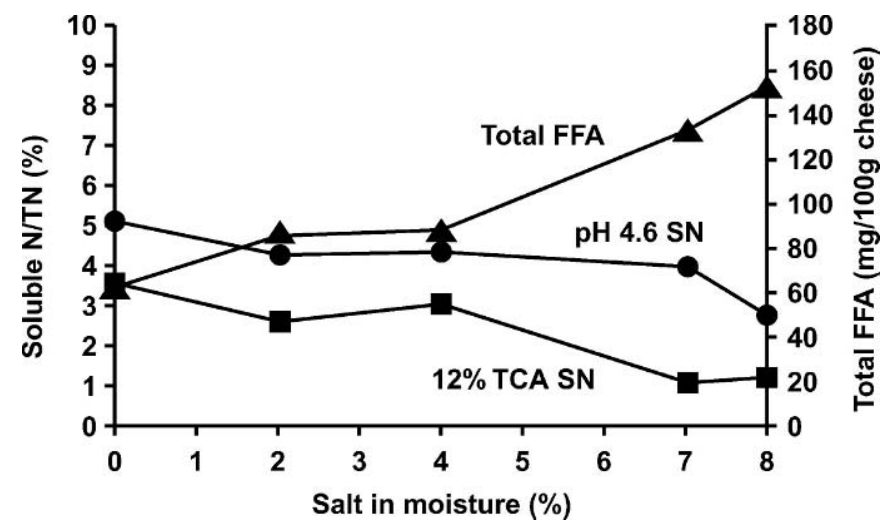

Figure 14. Impact of different levels of salt in moisture (0 to 8\%)

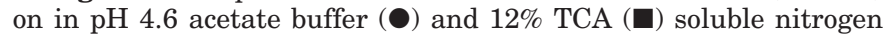
as a percentage of total nitrogen and on total FFA ( $\mathrm{mg} / 100 \mathrm{~g}$ of cheese) (A) content of cheese made by direct salting and held at $21^{\circ} \mathrm{C}$ for $15 \mathrm{~d}$.

to the surface of the block during brine salting or from the brine into the cheese, we conducted a simple follow up experiment. One batch of Ragusano cheese curd was produced as described previously (Melilli et al., 2003a) and was split into $52.6-\mathrm{kg}$ portions. One portion was stretched and formed into a rectangular block with no added salt, and the other portions had 2, 4, 6, and $8 \%$ added salt prior to stretching and forming into blocks. The cheese curd and added salt were mixed thoroughly to achieve uniform salt content throughout the curd prior to stretching. Each cheese was stretched separately in a different salt-water solution designed to avoid loss of salt from the curd into the stretching water (i.e., $0,4.4,8.2,11.7$, and $15.1 \%$ salt, respectively). The temperature of the cheese during stretching was 48 to $49^{\circ} \mathrm{C}$ for all treatments. After stretching, a 200-g sample was removed for analysis before forming the remaining cheese into a block. After the 5 blocks were held for $18 \mathrm{~h}$ at $18^{\circ} \mathrm{C}$, a 500 -g sample was removed from each block for analysis, and then the remainder of each block was vacuum packaged. There was no brine salting. All vacuum packaged blocks were placed in a $21^{\circ} \mathrm{C}$ incubator for $15 \mathrm{~d}$. The total FFA content, TN, pH 4.6 acetate buffer SN, $12 \%$ TCA SN, moisture, $\mathrm{pH}$, and salt content of each block were measured using the methods described earlier. In this experiment, the salt was uniform throughout each block of cheese during the $15 \mathrm{~d}$ at $21^{\circ} \mathrm{C}$, so there was no effect of migration of water from the interior to exterior positions within the blocks, only the direct effect of salt in moisture concentration on proteolysis and lipolysis. The cheese $\mathrm{pH}$ among treatments varied from 5.14 to 5.21 with no relationship to salt content. The extent of proteolysis and lipolysis over the range of salt in moisture from 0 to $8 \%$ is shown in Figure 14. While we could not achieve as high a salt in moisture as found in the exterior position of brine salted cheeses (i.e., up to 17\%), the trends for proteolysis and lipolysis with increasing salt in the moisture (Figure 14) were the same as seen for the brine-salted cheeses in Figure 9. Therefore, we have confirmed that increasing salt in moisture decreased proteolysis (as measured by $\mathrm{pH} 4.6$ acetate buffer SN/TN) and 12\% TCA SN/TN and increased lipolysis (as measured by the copper soap method) independent of the possible impacts of movement of water-soluble FFA from the brine into the cheese or from the interior to the exterior of the block of cheese with migration of moisture during brine salting.

\section{CONCLUSIONS}

Both proteolysis and lipolysis in Ragusano cheese increased with increasing brine temperature (from 12 to $24^{\circ} \mathrm{C}$ ) with the impact of incremental changes in brine temperature on proteolysis and lipolysis becoming larger with increasing brine temperature. Proteolysis was higher in the interior of the blocks where salt in moisture content was lower and brine temperature had more impact on proteolysis in the interior position in the block. However, the opposite was true for lipolysis. The total FFA content was higher at the exterior position of the block where salt in moisture was the highest and temperature had more impact on lipolysis at the exterior position where salt in moisture was high. This effect of increased salt concentration on lipolysis was confirmed with direct salted cheeses in a follow up experiment. Lipolysis increased with increasing salt in the moisture content of the direct salted cheeses. It is likely that migration of water-soluble FFA from the brine into the cheese and from the interior portion of the cheese to the exterior portion of the cheese also contributed to a higher level of FFA at the exterior portion of the blocks. As brine temperature increased, the profile of individual FFA released from triglycerides changed, with the proportion of short-chain FFA increasing with increasing brine temperature. This effect was largest at high salt in moisture content. Previous work (Melilli et al., 2003a) on the use of presalting before brining and use of lower brine concentration found that both presalting and lower brine concentration could deliver salt to the interior of the block more quickly and could possibly be used to reduce the incidence of early gas formation in Ragusano cheese. The current study has demonstrated that lower brine temperature will reduce the rate of salt uptake, but the direct effect of lower temperature to reduce the growth of bacteria may reduce gas production. Future work will focus on the combination of these approaches and their combined impact on salt penetration, gas production, and quality of Ragusano cheese. 


\section{ACKNOWLEDGMENTS}

The authors thank Giovanni Longombardo, Pat Wood, and Laura Landolf for technical assistance in cheese analysis and Rosario Tumino, Giovanni Tumino, Giuseppe Schembari, Sebastiano Campo, and Giovanni Marino for technical assistance in cheese making. Financial support was provided by Assessorato Agricoltura e Foreste della Regione Siciliana, Palermo, Italy.

\section{REFERENCES}

Association of Official Analytical Chemists International. 2000. 17th ed. Official Methods of Analysis. AOAC International, Gaithersburg, MD.

Barbano, D. M., K. Y. Chu, J. J. Yun, and P. S. Kindstedt. 1993. Contributions of coagulant, starter, and milk enzymes to proteolysis and browning in Mozzarella cheese. Pages 65 to 80 in Proceedings of the 30th Annual Marschall Italian Cheese Seminar. Rhodia-Marschall, Madison, WI.

Barbano, D. M., A. Renda, J. J. Yun, and P. S. Kindstedt. 1994a. Influence of cheese temperature and screw speed on Mozzarella cheese yield. Pages 1 to 10 in Proceedings of the 31st Annual Marschall Italian and Specialty Cheese Seminar. RhodiaMarschall, Madison, WI.

Barbano, D. M., J. J. Yun, and P. S. Kindstedt. 1994b. Mozzarella cheese making by a stirred curd, no brine procedure. J. Dairy Sci. 77:2687-2694.

Bier, M. 1955. Lipases. Pages 627 to 630 in Methods of Enzymology. S. P. Colowick and N. O. Kaplin, eds. Academic Press Inc., New York, NY.

Bynum, D. G., and D. M. Barbano. 1985. Whole milk reverse osmosis retentates for Cheddar cheese manufacture: Chemical changes during aging. J. Dairy Sci. 68:1-10.

Geurts, T. J., P. Walstra, and H. Mulder. 1972. Brine composition and the prevention of the defect "soft rind" in cheese. Neth. Milk Dairy J. 26:168-179.

Geurts, T. J., P. Walstra, and H. Mulder. 1974. Transport of salt and water during salting of cheese. 1. Analysis of the processes involved. Neth. Milk Dairy J. 28:102-129.

Glantz, S. A., and B. K. Slinker. 2001. Multicollinearity and what to do about it. Pages 185-187 in Primer of Applied Regression \& Analysis of Variance. 2nd ed. McGraw-Hill, Inc. New York, NY.

Grappin, R., T. C. Rank, and N. F. Olson. 1985. Primary proteolysis of cheese proteins during ripening: A review. J. Dairy Sci. 68:531-540.

Guinee, T. P., and P. F. Fox. 1983. Sodium chloride and moisture changes in Romano-type cheese during salting. J. Dairy Res. 50:511-518.

Guinee, T. P., and P. F. Fox. 1986. Influence of cheese geometry on the movement of sodium chloride and water during brining. Irish J. Food Sci Technol. 10:73-96.

International Dairy Federation. 1991. Determination of individual FFA-reference method. Monograph on determination of FFA in milk and milk products. Int. Fed. Bull. 265:41-44.
Kindstedt, P. S., M. R. Guo, W. H. Viotto, J. J. Yun, and D. M. Barbano. 1995. Effect of screw speed and residence time at high stretching temperature on composition, proteolysis, functional properties, and the water phase of Mozzarella cheese. Pages 56 to 72 in Proceedings of the 32nd Annual Marschall Italian \& Specialty Cheese Seminar. Rhodia-Marschall, Madison, WI.

Kindstedt, P. S., L. J. Kiely, and J. A. Gilmore. 1992. Variation in composition and functional properties within brine salted Mozzarella cheese. J. Dairy Sci. 75:2913-2921.

Kindstedt, P. S., and F. V. Kosikowski. 1985. Improved complexometric determination of calcium in cheese. J. Dairy Sci. 68:806-809.

Lee, H. J., N. F. Nelson, and D. B. Lund. 1980. Diffusion of salt, fatty acids, and esterases in Mozzarella cheese. J. Dairy Sci. 63:513-522.

Licitra, G., G. Portelli, P. Campo, G. Longombardo, G. Farina, S. Carpino, and D. M. Barbano. 1998. Technology to produce Ragusano cheese: A survey. J. Dairy Sci. 81:3343-3349.

Lictitra, G., P. Campo, M. Manenti, G. Portelli, S. Scuderi, S. Carpino, and D. M. Barbano. 2000. Composition of Ragusano cheese during aging. J. Dairy Sci. 83:404-411.

Lynch, J. M., D. M. Barbano, D. E. Bauman, G. F. Hartnell, and M. A. Nemeth. 1992. Effect of a prolonged-release formuation of $\mathrm{N}$ methionyl bovine somatotropin (Sometribove) on milk fat. J. Dairy Sci. 75:1794-1809.

May, Y., D M. Barbano, and M. Santos. 2003. Effect of $\mathrm{CO}_{2}$ addition to raw milk on proteolysis and lipolysis at $4^{\circ} \mathrm{C}$. J. Dairy Sci. 86:1616-1631.

Melilli, C., D. M. Barbano, G. Licitra, G. Tumino, G. Farina, and S. Carpino. 2003a. Influence of presalting and brine concentration on salt uptake by Ragusano cheese. J. Dairy Sci. 86:1083-1100.

Melilli, C., D. M. Barbano, G. Licitra, G. Tumino, G. Farina, and S. Carpino. 2003b. Influence of temperature of salt brine concentration on salt uptake by Ragusano cheese. J. Dairy Sci. 86:27992812.

Nelson, J. H., R. G. Jensen, and R. E. Pitas. 1977. Pregastric esterase and other oral lipases-A review. J. Dairy Sci. 60:327-362.

Pastorino, A. J., C. L. Hansen, and D. J. McMahon. 2003. Effect of salt on structure-function relationships of cheese. J. Dairy Sci. 86:60-69.

Rank, T. C., R. Grappin, and N. F. Olson. 1985. Secondary proteolysis of cheese during ripening: A review. J. Dairy Sci. 68:801-805.

Renda, A., D. M. Barbano, J. J. Yun, P. S. Kindstedt, and S. J. Mulvaney. 1997. Influence of screw speeds of the mixer at low temperature on characteristics of Mozzarella cheese. J. Dairy Sci. 80:1901-1907.

Resmini, P., G. Volonterio, S. Annibaldi, and G. Ferri. 1974. Studio sulla diffusione del sale nel formaggio Parmigiano-Reggiano mediante l'uso di $\mathrm{Na}^{36} \mathrm{Cl}$. Sci. Tecn. Latt. Casearia 25:149-166.

Shipe, W. F., G. F. Senyk, and K. B. Fountain. 1980. Modified copper soap solvent extraction method for measuring free fatty acids in milk. J. Dairy Sci. 63:193-198.

Thomas, T. D., and K. N. Pearce. 1981. Influence of salt on lactose fermentation and proteolysis in Cheddar cheese. N.Z. J. Dairy Sci. Technol. 16:253-259.

Turhan, M., and G. Kaletunç. 1992. Modelling of salting diffusion in white cheese during long term brining. J. Food Sci. 57:1082-1085. 